\title{
Tectonic events, continental intraplate volcanism, and mantle plume activity in northern Arabia: Constraints from geochemistry and Ar-Ar dating of Syrian lavas
}

\author{
M.-S. Krienitz \\ Institut für Geowissenschaften, Universität Kiel, Olshausenstrasse 40, D-24118 Kiel, Germany \\ Now at Helmholtz-Zentrum Potsdam, Deutsches GeoForschungsZentrum, Telegrafenberg, D-14473 Potsdam, Germany \\ (krieni@gfz-potsdam.de)
}

K. M. Haase

GeoZentrum Nordbayern, Schlossgarten 5, D-91054 Erlangen, Germany

K. Mezger

Institut für Mineralogie, Universität Münster, Corrensstrasse 24, D-48149 Münster, Germany

P. van den Bogaard

Leibniz-Institut für Meereswissenschaften an der Universität Kiel (IFM-GEOMAR), Wischhofstrasse 1-3, D-24148 Kiel, Germany

V. Thiemann

Institut für Mineralogie, Universität Münster, Corrensstrasse 24, D-48149 Münster, Germany

\section{A. Shaikh-Mashail}

Faculty of Civil Engineering, University of Aleppo, P.O. Box 5427, Aleppo, Syria

[1] $\mathrm{New}{ }^{40} \mathrm{Ar} /{ }^{39} \mathrm{Ar}$ ages combined with chemical and $\mathrm{Sr}, \mathrm{Nd}$, and $\mathrm{Pb}$ isotope data for volcanic rocks from Syria along with published data of Syrian and Arabian lavas constrain the spatiotemporal evolution of volcanism, melting regime, and magmatic sources contributing to the volcanic activity in northern Arabia. Several volcanic phases occurred in different parts of Syria in the last 20 Ma that partly correlate with different tectonic events like displacements along the Dead Sea Fault system or slab break-off beneath the Bitlis suture zone, although the large volume of magmas and their composition suggest that hot mantle material caused volcanism. Low $\mathrm{Ce} / \mathrm{Pb}(<20), \mathrm{Nb} / \mathrm{Th}(<10)$, and $\mathrm{Sr}, \mathrm{Nd}$, and $\mathrm{Pb}$ isotope variations of Syrian lavas indicate the role of crustal contamination in magma genesis, and contamination of magmas with up to $30 \%$ of continental crustal material can explain their ${ }^{87} \mathrm{Sr}{ }^{86} \mathrm{Sr}$. Fractionation-corrected major element compositions and REE ratios of uncontaminated lavas suggest a pressure-controlled melting regime in western Arabia that varies from shallow and high-degree melt formation in the south to increasingly deeper regions and lower extents of the beginning melting process northward. Temperature estimates of calculated primary, crustally uncontaminated Arabian lavas indicate their formation at elevated mantle temperatures $\left(\mathrm{T}_{\text {excess }} \sim 100-200^{\circ} \mathrm{C}\right)$ being characteristic for their generation in a plume mantle region. The $\mathrm{Sr}, \mathrm{Nd}$, and $\mathrm{Pb}$ isotope systematic of crustally uncontaminated Syrian lavas reveal a sublithospheric and a mantle plume source involvement in their formation, whereas a (hydrous) lithospheric origin of lavas can be excluded on the basis of negative correlations between $\mathrm{Ba} / \mathrm{La}$ and $\mathrm{K} / \mathrm{La}$. The characteristically high ${ }^{206} \mathrm{~Pb} /{ }^{204} \mathrm{~Pb}(\sim 19.5)$ of the mantle plume source can be explained by material 
entrainment associated with the Afar mantle plume. The Syrian volcanic rocks are generally younger than lavas from the southern Afro-Arabian region, indicating a northward progression of the commencing volcanism since the arrival of the Afar mantle plume beneath Ethiopia/Djibouti some $30 \mathrm{Ma}$ ago. The distribution of crustally uncontaminated high ${ }^{206} \mathrm{~Pb} /{ }^{204} \mathrm{~Pb}$ lavas in Arabia indicates a spatial influence of the Afar plume of $\sim 2600 \mathrm{~km}$ in northward direction with an estimated flow velocity of plume material on the order of $22 \mathrm{~cm} / \mathrm{a}$.

Components: 18,945 words, 10 figures, 3 tables.

Keywords: Afar; intraplate volcanism; mantle plume; Syria; ${ }^{40} \mathrm{Ar} /{ }^{39} \mathrm{Ar}$ ages.

Index Terms: 1037 Geochemistry: Magma genesis and partial melting (3619); 1033 Geochemistry: Intra-plate processes (3615, 8415); 1040 Geochemistry: Radiogenic isotope geochemistry.

Received 22 September 2008; Revised 5 February 2009; Accepted 13 February 2009; Published 8 April 2009.

Krienitz, M.-S., K. M. Haase, K. Mezger, P. van den Bogaard, V. Thiemann, and M. A. Shaikh-Mashail (2009), Tectonic events, continental intraplate volcanism, and mantle plume activity in northern Arabia: Constraints from geochemistry and Ar-Ar dating of Syrian lavas, Geochem. Geophys. Geosyst., 10, Q04008, doi:10.1029/2008GC002254.

\section{Introduction}

[2] Basaltic intraplate volcanism is abundant both in the ocean basins and on the continents and has occurred through all geologic times, but the cause for the generation of many intraplate volcanic provinces is only poorly understood. Geochronology in combination with the study of chemical and isotopic compositions of volcanic rocks provides an important tool to determine the relations between magma sources, eruption and plate tectonics. For example, intraplate lavas in oceanic regimes often occur along age progressive chains, which have been explained to result from the activity of deep mantle plumes that produce magmas even beneath thick lithosphere [e.g., Duncan and Richards, 1991]. Many continental intraplate lavas occur close to rift systems and lithospheric thinning may also provide a mechanism to generate magmas in the upper mantle [McKenzie and Bickle, 1988]. The Red Sea region and Arabia represent one of the youngest and largest continental intraplate basaltic provinces where magmas may have formed because of both lithospheric extension and mantle plume activity.

[3] The petrogenesis and magma source regions in southwestern Arabia are relatively well characterized and magma genesis is associated with rifting of the Red Sea and Afar mantle plume activity [e.g., Bohannon et al., 1989; Schilling, 1973]. However, the causes of volcanism in northern Arabia are less clear and the far-scale influence of the Afar mantle plume is a major open question. To explain volcanism in northern Arabia several models have been proposed: (1) northwestward channeling of Afar mantle plume material [Camp and Roobol, 1992], (2) the existence of a (separate) mantle plume [Camp and Roobol, 1992], (3) melting of mantle lithosphere by heat conduction from sublithospheric anomalous hot mantle [e.g., Weinstein et al., 2006], (4) progressive lithospheric thinning and tapping of lithospheric (fossil plume material) to asthenospheric sources [Bertrand et al., 2003; Lustrino and Sharkov, 2006; Shaw et al., 2003; Stein and Hofmann, 1992], and (5) slab break-off involving asthenospheric mantle sources [e.g., Krienitz et al., 2006].

[4] We present new major, trace element and $\mathrm{Sr}$, $\mathrm{Nd}$, and $\mathrm{Pb}$ isotope data and ${ }^{40} \mathrm{Ar} /{ }^{39} \mathrm{Ar}$ ages for Syrian lavas along the northern margin of this Arabian large igneous province and use published geochemical, isotope and age data from Syrian volcanic rocks [Krienitz et al., 2006, 2007] (see Table S1) and Arabia (see captions to Figures 3 and 5 for compilation) in order to investigate the relationship of these lavas to the geochemical and geodynamic processes along the Red Sea margin and thus over a distance of several thousand kilometers. ${ }^{1}$

\section{Geological Framework}

[5] Syria is located at the northwestern end of Arabia close to the continent-continent collision zone of the Bitlis suture (Figure 1). The Dead Sea

${ }^{1}$ Auxiliary materials are available in the HTML. doi:10.1029/ 2008GC002254. 

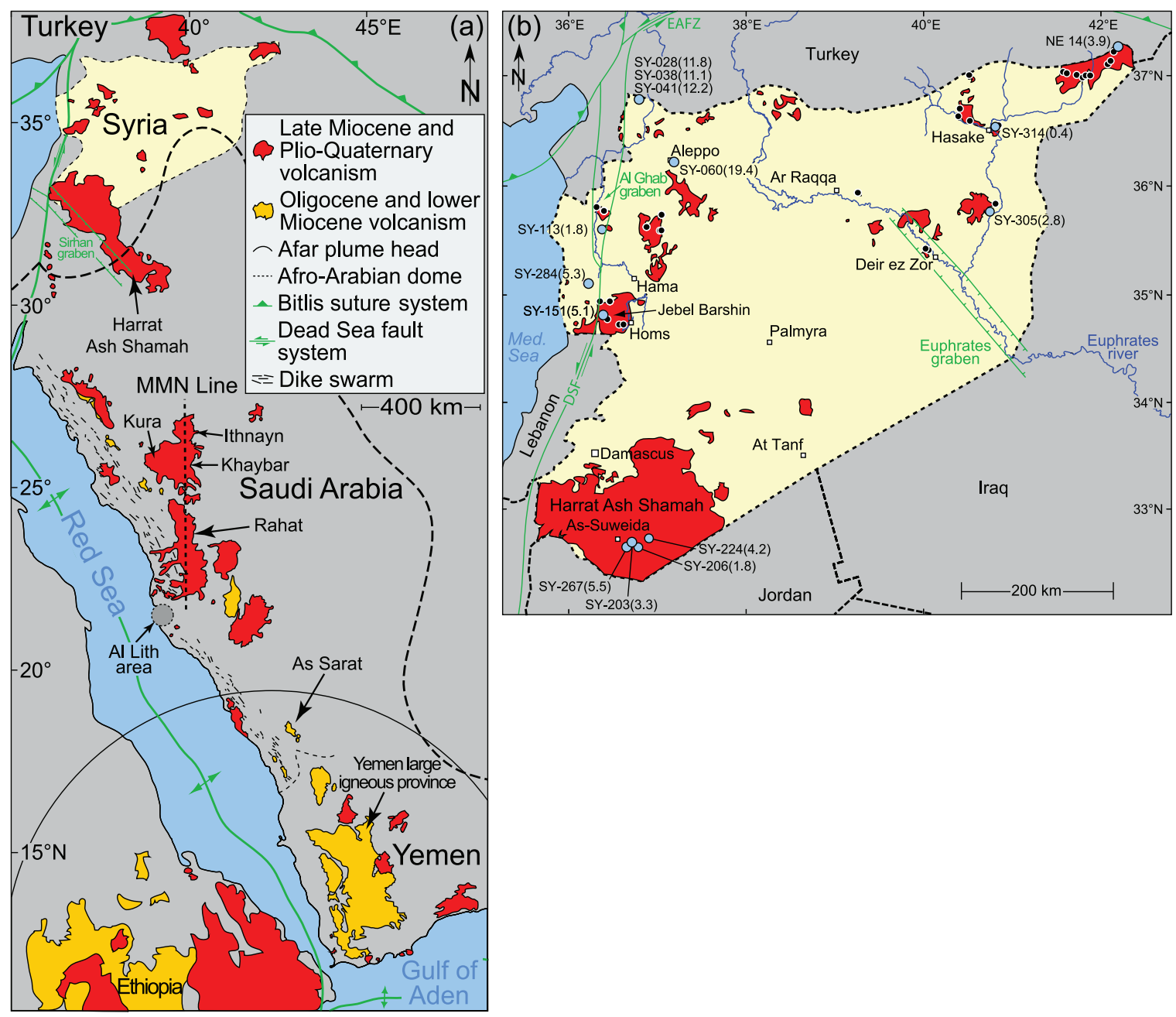

Figure 1. (a) Distribution of volcanic fields along western Arabia and the Gulf of Aden region modified after Bertrand et al. [2003], Pik et al. [1998], and Krienitz et al. [2007]. The presumed area of the flattened Afar plume head is after Schilling et al. [1992], and the dimension of the Afro-Arabian dome is after Camp and Roobol [1992]. The MMN (Makkah-Madinah-Nafud) Line is a north trending volcanic axis of Harrats Rahat, Khaybar, and Ithnayn forming a single vent system [Camp et al., 1991]. (b) Simplified map of Syria showing the distribution of volcanism. Locations of samples used for isotope analyses in this study are shown as small black circles. Dated volcanic rocks are indicated by large blue circles together with sample names and ages in Ma. Additional geochemical and isotope data to the samples are given by Krienitz et al. [2006, 2007] (see also Table S1). Ages of samples SY-203 and SY-224 are from Krienitz et al. [2007]. DSF, Dead Sea Fault system; EAFZ, East Anatolian fault zone.

Fault, a major plate boundary, forms a large strikeslip fault system in western Syria where about $100 \mathrm{~km}$ of lateral movement has occurred since the middle Miocene [Bartov et al., 1980]. Minor extensional movement led to the formation of the $\mathrm{Al}$ Ghab graben in the northern part of the Dead Sea Fault (Figure 1) and several small NW-SE striking graben structures in Syria and neighboring countries like the Euphrates Fault system [Brew et al., 2001] and two grabens close to the Harrat Ash Shamah volcanic field [Almond, 1986, Figure 1]. Syria is covered by numerous volcanic centers which can be divided into five major areas: (1) the region around Aleppo, (2) the Euphrates graben and continuing into Turkey, (3) the Al Ghab graben as part of the Dead Sea Transform Fault in NW Syria, (4) the large volcano near Homs, and (5) the Syrian part of Harrat Ash Shamah (Figure 1). The Harrat Ash Shamah (HAS) is the largest volcanic plateau of Arabia and covers large parts of southern Syria extending about $500 \mathrm{~km}$ from Israel through Syria and Jordan into Saudi Arabia and reaching a maximum thickness of $1500 \mathrm{~m}$ [e.g., Guba and Mustafa, 1988]. This volcanic plateau represents a thick stack of lava flows which are cut by dikes and covered by scoria cones. Close to Homs lies the 
Barshin volcano, a smaller lava plateau, which is truncated and offset in its western part by the northern Dead Sea Transform Fault [Gomez et al., 2006]. Lava flows and small eruption centers occur within the Al Ghab graben. Large regions between Hama and Aleppo are covered by thin lava flows, while small eruption centers with up to $300 \mathrm{~m}$ thick lava flows occur along the border with Turkey (Figure 1). In NE Syria lavas mainly occur as thin flows and rows of scoria cones. A few K-Ar ages obtained for Syrian volcanics indicate a Cretaceous phase of magmatism between $130 \mathrm{Ma}$ to $90 \mathrm{Ma}$ [Mouty et al., 1992], but most ages show that volcanism is younger, starting at about $26 \mathrm{Ma}$ and probably lasting until the Holocene [Demir et al., 2007; Giannérini et al., 1988; Mouty et al., 1992; Sharkov et al., 1994, 1998].

\section{Methods}

[6] The full analytical details for major and trace element analyses, $\mathrm{Sr}, \mathrm{Nd}$ and $\mathrm{Pb}$ isotope determinations as well as for the Ar-Ar dating procedure are given in the auxiliary material. The results are listed in Tables 1-3.

\section{Results}

\subsection{The ${ }^{40} \mathrm{Ar} /{ }^{39} \mathrm{Ar}$ Dating}

[7] Most of the high-resolution incremental heating analyses yield well-defined age plateaus, with numerous consecutive gas release steps in the midtemperature range comprising a significant fraction $(>50 \%)$ of the cumulative ${ }^{39} \mathrm{Ar}$ yield and apparent ages identical within analytical uncertainty ( $2 \sigma$; excluding uncertainties in the $\mathrm{J}$ value, Figure 2). Elevated apparent ages at the edges of many spectra and systematically higher total gas ("K-Ar") ages demonstrate the efficiency of the incremental heating procedure in selectively releasing low-, medium-, and high-temperature Ar reservoirs i.e., alteration products with or without ${ }^{39} \mathrm{Ar}$ recoil, primary K-bearing mineral phases (e.g., plagioclase), and mafic high-temperature mineral phases with inherited excess ${ }^{40} \mathrm{Ar}$, clinopyroxene and olivine, respectively.

[8] Matrix analyses SY-234, SY-283, and SY-314 and feldspar analysis SY-206 show poorly defined spectra but are included in the discussion to demonstrate the limits of the analytical approach (Figure 2; SY-206 not shown). Matrix analyses SY-234 and SY-283 display acceptable single-step preci- sions, but the overall spectra are strongly disturbed in the high-temperature gas release region, which yields apparent ages $\left({ }^{40} \mathrm{Ar} /{ }^{39} \mathrm{Ar}\right.$ ratios) that are significantly higher than the small mediumtemperature plateau intervals. These unrealistically old ages are most likely derived from groundmass clinopyroxene with initial ${ }^{40} \mathrm{Ar} /{ }^{36} \mathrm{Ar}$ ratios $>295.5$ (Figure 2).

[9] Inverse isochron analysis of the entire incremental heating data sets yields isochrons with acceptable mean square weighted deviates for all samples except SY-041 and SY-283 (Table 3). Isochron ages are generally identical to the plateau ages within $1 \sigma$ or $2 \sigma$ uncertainties, but also yield virtual initial ${ }^{40} \mathrm{Ar} /{ }^{36} \mathrm{Ar}$ ratios slightly higher than atmosphere (296 to 305), reflecting either systematically elevated initial ${ }^{40} \mathrm{Ar} /{ }^{36} \mathrm{Ar}$ ratios in most samples, or counterclockwise tilting of the isochron (mixing) lines from low-temperature, highatmosphere gas releases due to secondary mineral and ${ }^{39} \mathrm{Ar}$ recoil. Isochron ages, however, are not systematically younger than the plateau ages, as would be expected from counterclockwise rotation (Table 3).

\subsection{Major Element Compositions and Trace Element Ratios}

[10] For convenience in the data presentation and following discussions all Syrian lavas analyzed during this study are supplemented by previously published data from Syria and are divided into four groups depending on their spatial occurrence: (1) the NW Syria group comprises lavas that have been erupted north of Hama, around Aleppo and close to the Turkish border (data from Krienitz et al. [2006]); (2) the NE Syria group is represented by lavas occurring in the Euphrates graben region, around Hasake and in the northeasternmost part of the country; (3) the Dead Sea Transform Fault (DSF) group includes volcanic rocks from the $\mathrm{Al}$ Ghab graben and the Jebel Barshin volcano near Homs; and (4) the Harrat Ash Shamah (HAS) group comprises all lavas from the HAS field in southern Syria, Jordan and Israel (data from Altherr et al. [1990], Bertrand et al. [2003], Krienitz et al. [2007], Shaw et al. [2003], Stein and Hofmann [1992] and Weinstein et al. [2006]) in order to constrain the large-scale regional evolution of the magma generation in the Arabian region (Figure 1). The Syrian samples recovered further north than the HAS (i.e., the NE and DSF groups; Table 1) are also supplemented by pub- 
Table 1 (Sample). Major (XRF) and Trace Element (XRF and ICP-MS) Analyses of the Syrian Samples [The full Table 1 is available in the HTML version of this article]

\begin{tabular}{|c|c|c|c|c|c|c|c|c|c|}
\hline & \multicolumn{9}{|c|}{ Sample } \\
\hline & SY-049 & SY-050 & SY-052 & SY-053 & SY-054 & SY-057 & SY-091 & SY-092 & SY-093 \\
\hline Group & DSF & DSF & DSF & DSF & DSF & DSF & DSF & DSF & DSF \\
\hline Latitude $\left({ }^{\circ} \mathrm{N}\right)$ & $35^{\circ} 43^{\prime} 28^{\prime \prime}$ & $35^{\circ} 43^{\prime} 28^{\prime \prime}$ & $35^{\circ} 43^{\prime} 26^{\prime \prime}$ & $35^{\circ} 43^{\prime} 26^{\prime \prime}$ & $35^{\circ} 43^{\prime} 11^{\prime \prime}$ & $35^{\circ} 43^{\prime} 11^{\prime \prime}$ & $35^{\circ} 45^{\prime} 22^{\prime \prime}$ & $35^{\circ} 45^{\prime} 22^{\prime \prime}$ & $35^{\circ} 45^{\prime} 22^{\prime \prime}$ \\
\hline Longitude $\left({ }^{\circ} \mathrm{E}\right)$ & $37^{\circ} 03^{\prime} 44^{\prime \prime}$ & $37^{\circ} 03^{\prime} 44^{\prime \prime}$ & $37^{\circ} 03^{\prime} 30^{\prime \prime}$ & $37^{\circ} 03^{\prime} 30^{\prime \prime}$ & $37^{\circ} 03^{\prime} 26^{\prime \prime}$ & $37^{\circ} 03^{\prime} 26^{\prime \prime}$ & $36^{\circ} 24^{\prime} 25^{\prime \prime}$ & $36^{\circ} 24^{\prime} 25^{\prime \prime}$ & $36^{\circ} 24^{\prime} 25^{\prime \prime}$ \\
\hline Elevation (m) & 294 & 294 & - & - & 289 & 289 & 360 & 360 & 360 \\
\hline Rock type $\mathrm{a}^{\mathrm{a}}$ & $\mathrm{AB}$ & $\mathrm{AB}$ & $\mathrm{AB}$ & $\mathrm{AB}$ & $\mathrm{AB}$ & $\mathrm{AB}$ & $\mathrm{B}$ & $\mathrm{B}$ & B \\
\hline $\mathrm{SiO}_{2}($ wt \%) & 45.49 & 45.34 & 46.19 & 46.39 & 42.85 & 44.19 & 40.10 & 41.12 & 40.96 \\
\hline $\mathrm{TiO}_{2}$ & 2.47 & 2.22 & 2.40 & 2.17 & 2.02 & 2.10 & 3.10 & 3.04 & 3.01 \\
\hline $\mathrm{Al}_{2} \mathrm{O}_{3}$ & 13.65 & 13.73 & 13.87 & 13.99 & 12.84 & 13.55 & 12.96 & 13.40 & 12.91 \\
\hline $\mathrm{Fe}_{2} \mathrm{O}_{3}^{\mathrm{T}}$ & 14.18 & 13.12 & 13.44 & 13.06 & 12.36 & 12.91 & 13.53 & 13.94 & 13.74 \\
\hline $\mathrm{MnO}$ & 0.19 & 0.17 & 0.17 & 0.17 & 0.16 & 0.16 & 0.18 & 0.21 & 0.20 \\
\hline $\mathrm{MgO}$ & 7.51 & 7.84 & 6.90 & 8.65 & 7.86 & 6.63 & 7.69 & 7.76 & 8.28 \\
\hline $\mathrm{CaO}$ & 9.98 & 11.10 & 9.97 & 10.20 & 12.74 & 12.71 & 10.99 & 11.27 & 10.97 \\
\hline $\mathrm{Na}_{2} \mathrm{O}$ & 2.85 & 3.39 & 3.21 & 3.35 & 2.97 & 2.77 & 4.42 & 4.46 & 4.40 \\
\hline $\mathrm{K}_{2} \mathrm{O}$ & 0.90 & 0.98 & 1.06 & 0.98 & 0.89 & 0.91 & 0.80 & 1.05 & 0.97 \\
\hline $\mathrm{P}_{2} \mathrm{O}_{5}$ & 0.42 & 0.41 & 0.43 & 0.40 & 0.41 & 0.42 & 2.16 & 2.18 & 2.09 \\
\hline L.O.I. & 2.92 & 2.18 & 2.23 & 1.14 & 5.23 & 4.29 & 2.44 & 2.05 & 1.43 \\
\hline Total & 100.56 & 100.48 & 99.87 & 100.50 & 100.33 & 100.64 & 98.37 & 100.48 & 98.96 \\
\hline Mg-no ${ }^{\mathrm{b}}$ & 0.55 & 0.58 & 0.54 & 0.61 & 0.60 & 0.54 & 0.57 & 0.56 & 0.58 \\
\hline $\mathrm{Li}(\mathrm{ppm})$ & - & - & - & 14.7 & 16.0 & - & 2.53 & - & - \\
\hline $\mathrm{Sc}$ & - & - & - & 18.6 & 18.0 & - & 11.1 & - & - \\
\hline V & - & - & - & - & - & - & 135 & - & - \\
\hline $\mathrm{Cr}$ & 283 & 276 & 261 & 302 & 270 & 264 & 125 & 215 & 216 \\
\hline $\mathrm{Co}$ & - & - & - & 55.1 & 50.3 & - & 36.7 & - & - \\
\hline $\mathrm{Ni}$ & 233 & 233 & 234 & 227 & 195 & 218 & 97.5 & 146 & 149 \\
\hline $\mathrm{Cu}$ & - & - & - & 60.7 & 76.0 & - & 32.6 & - & - \\
\hline $\mathrm{Zn}$ & 125 & 108 & 119 & 103 & 97.6 & 107 & 104 & 132 & 133 \\
\hline $\mathrm{Ga}$ & - & - & - & - & - & - & - & - & - \\
\hline $\mathrm{Rb}$ & 12 & 13 & 14 & 12.7 & 11.7 & 10 & 8.05 & 13 & 14 \\
\hline $\mathrm{Y}$ & - & - & - & 17.5 & 17.0 & - & 28.2 & - & - \\
\hline Cs & - & - & - & 0.211 & 0.151 & - & 0.434 & - & - \\
\hline $\mathrm{Sr}$ & 631 & 592 & 626 & 979 & 613 & 626 & 2216 & 2228 & 2133 \\
\hline $\mathrm{Ba}$ & 474 & 302 & - & 203 & 1089 & 436 & 1413 & 932 & - \\
\hline $\mathrm{Zr}$ & 254 & 240 & 199 & 142 & 133 & 244 & 325 & 729 & 468 \\
\hline $\mathrm{Hf}$ & - & - & - & 4.10 & 3.92 & - & 7.82 & - & - \\
\hline $\mathrm{Nb}$ & - & - & - & 26.8 & 24.1 & - & 114 & - & - \\
\hline $\mathrm{Ta}$ & - & - & - & 1.83 & 1.64 & - & 5.84 & - & - \\
\hline $\mathrm{Pb}$ & - & - & - & 2.35 & 2.80 & - & 4.84 & - & - \\
\hline Th & - & - & - & 2.70 & 2.72 & - & 9.65 & - & - \\
\hline U & - & - & - & 0.883 & 1.30 & - & 2.79 & - & - \\
\hline $\mathrm{La}$ & - & - & - & 21.7 & 21.6 & - & 115 & - & - \\
\hline $\mathrm{Ce}$ & - & - & - & 44.6 & 43.9 & - & 216 & - & - \\
\hline $\operatorname{Pr}$ & - & - & - & 5.44 & 5.31 & - & 24.2 & - & - \\
\hline $\mathrm{Nd}$ & - & - & - & 22.8 & 22.0 & - & 89.0 & - & - \\
\hline $\mathrm{Sm}$ & - & - & - & 5.30 & 5.05 & - & 15.4 & - & - \\
\hline $\mathrm{Eu}$ & - & - & - & 1.77 & 1.65 & - & 4.66 & - & - \\
\hline $\mathrm{Gd}$ & - & - & - & 5.29 & 5.03 & - & 12.3 & - & - \\
\hline $\mathrm{Tb}$ & - & - & - & 0.757 & 0.728 & - & 1.62 & - & - \\
\hline Dy & - & - & - & 4.13 & 4.01 & - & 7.63 & - & - \\
\hline Ho & - & - & - & 0.739 & 0.726 & - & 1.26 & - & - \\
\hline $\mathrm{Er}$ & - & - & - & 1.85 & 1.81 & - & 2.93 & - & - \\
\hline $\mathrm{Tm}$ & - & - & - & 0.241 & 0.241 & - & 0.351 & - & - \\
\hline $\mathrm{Yb}$ & - & - & - & 1.49 & 1.49 & - & 2.02 & - & - \\
\hline $\mathrm{Lu}$ & - & - & - & 0.208 & 0.210 & - & 0.278 & - & - \\
\hline
\end{tabular}

${ }^{\mathrm{a}}$ Rock type after TAS: B, basanite; AB, alkali basalt; T, tholeiite; H, hawaiite; PT, phonotephrite; F, foidite; RM, reference material.

${ }^{\mathrm{b}} \mathrm{Mg}$-no., $\mathrm{Mg} /\left(\mathrm{Mg}+\mathrm{Fe}^{2+}\right)$, assuming $\mathrm{FeO}=0.85 \mathrm{Fe}^{\mathrm{T}}$; n.d., not detected. 


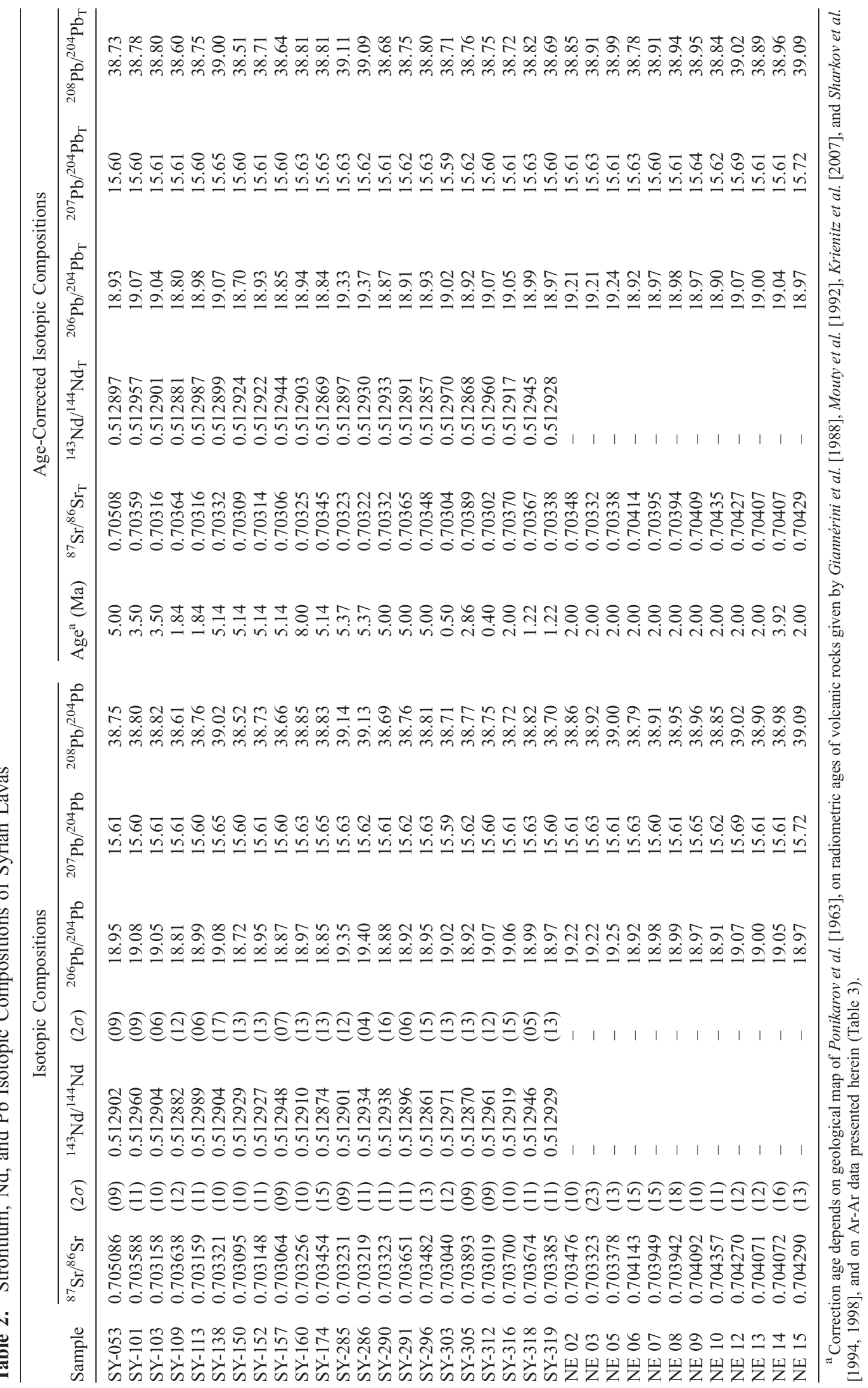




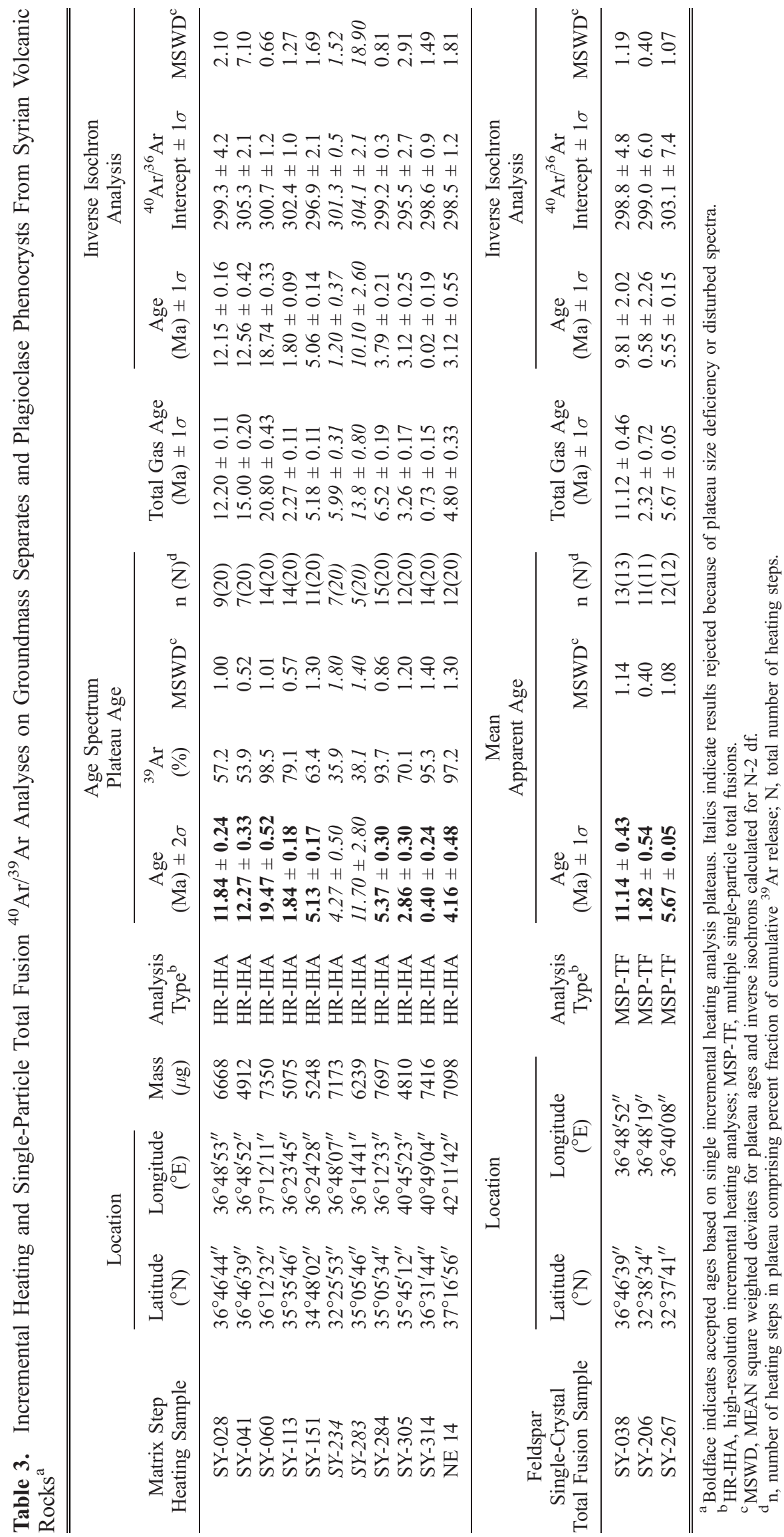



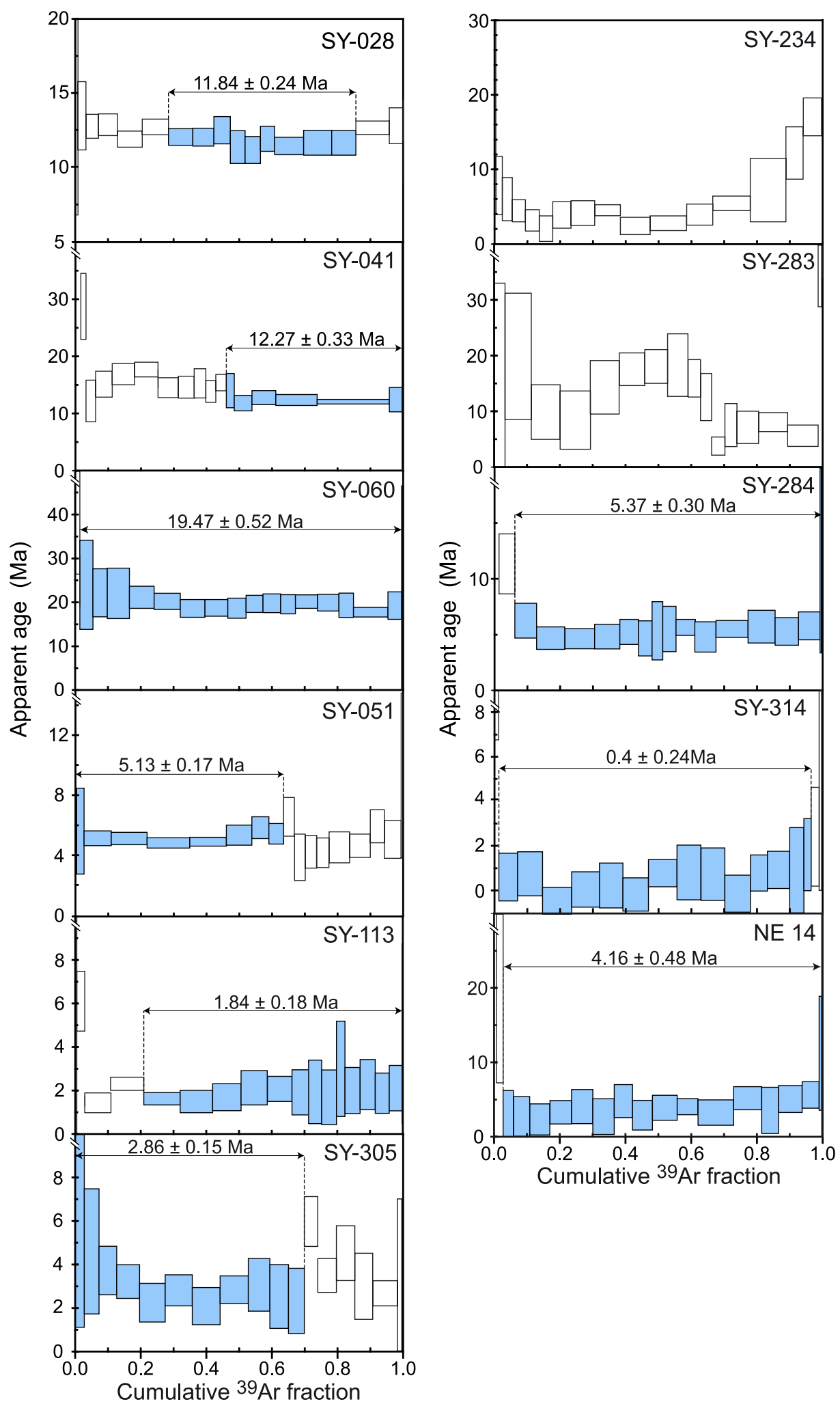

Figure 2. Microcrystalline groundmass ${ }^{40} \mathrm{Ar} /{ }^{39} \mathrm{Ar}$ incremental heating analyses. Reported ${ }^{40} \mathrm{Ar} /{ }^{39} \mathrm{Ar}$ dates are weighted age determinates and errors of the plateau fractions at the $2 \sigma$ confidence level. Plateau ranges and ${ }^{39} \mathrm{Ar}$ fractions as indicated. All samples were analyzed using Taylor Creek Rhyolite TCR sanidine (27.92 Ma [Duffield and Dalrymple, 1990]) as irradiation standard. 

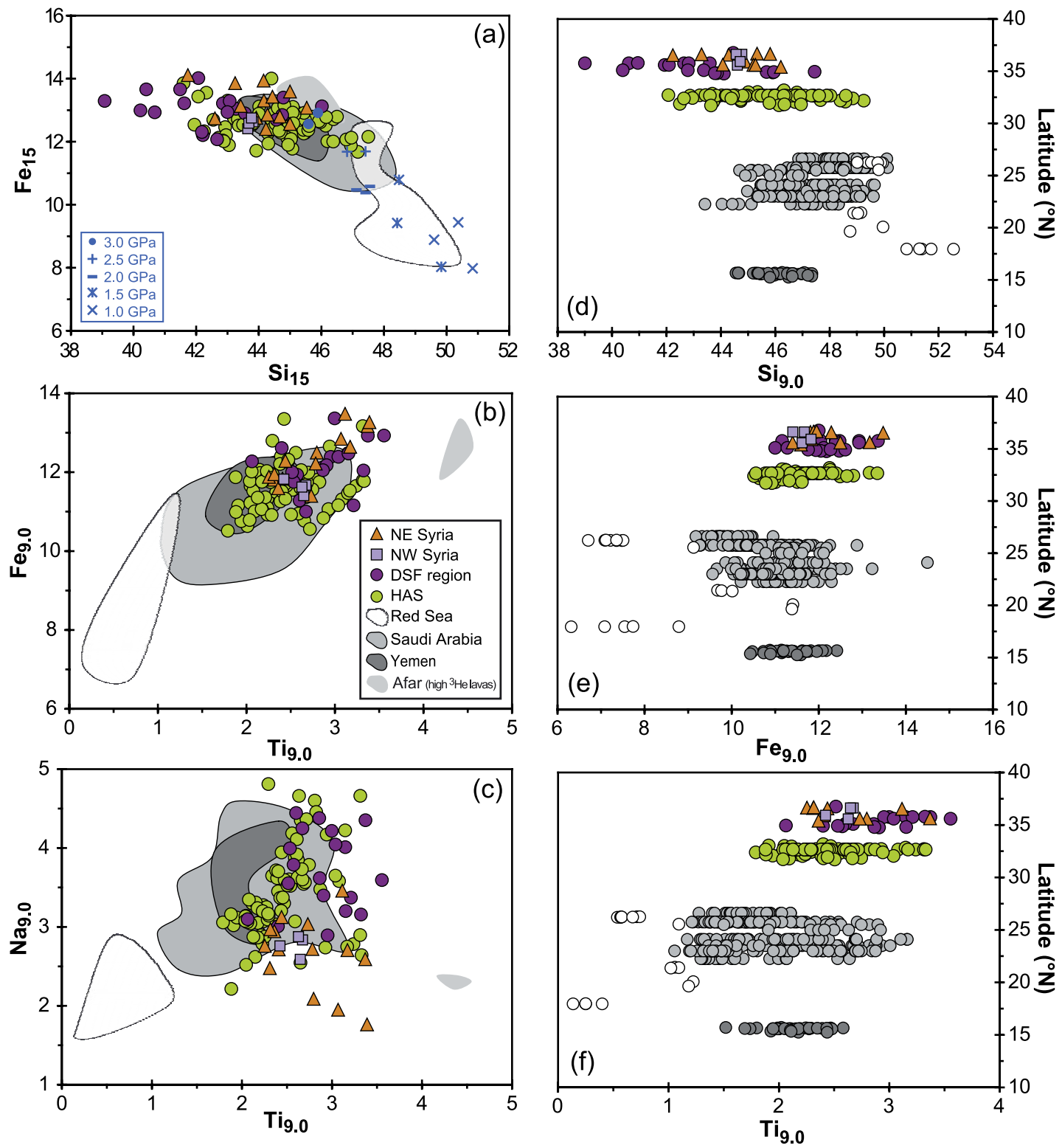

Figure 3. (a) Fractionation-corrected and olivine-adjusted $\mathrm{Si}\left(\mathrm{Si}_{15}\right)$ versus $\mathrm{Fe}\left(\mathrm{Fe}_{15}\right)$ compositions of crustally uncontaminated lavas from the Arabian region (see caption of Figure 10 for olivine addition procedure). (b) Fractionation-corrected $\mathrm{Ti}\left(\mathrm{Ti}_{9.0}\right.$ ) versus $\mathrm{Fe}_{9.0}$ and (c) $\mathrm{Ti}_{9.0}$ versus $\mathrm{Na}_{9.0}$ as well as (d) $\mathrm{Si}_{9.0}$, (e) $\mathrm{Fe}_{9.0}$, and (f) $\mathrm{Ti}_{9.0}$ versus latitude of crustally uncontaminated Arabian lavas. Note that all lavas were fractionation corrected to a $\mathrm{MgO}$ value of 9 wt \% prior to plotting. Additionally shown in Figure $3 \mathrm{a}$ are the results of peridotite melting experiments made at different pressures (blue) [Hirose and Kushiro, 1993]. Data sources are as follows: Syrian groups (DSF, NE, and NW), this work and Demir et al. [2007], Krienitz et al. [2006], and Lustrino and Sharkov [2006]; Harrat Ash Shamah (HAS), Krienitz et al. [2007], Shaw et al. [2003], and Weinstein et al. [2006]; Red Sea, Altherr et al. [1988], Eissen et al. [1989], and Haase et al. [2000]; Afar, Pik et al. [1998] and Pik et al. [1999]; Yemen, Baker et al. [1996b, 1997] and Manetti et al. [1991]; Saudi Arabia, Camp and Roobol [1989] and Camp et al. [1991].

lished data [Bertrand et al., 2003; Krienitz et al., 2006; Lustrino and Sharkov, 2006].

[11] Assessing spatiotemporal variations of primary lava compositions in a volcanic province like the western Arabian region requires the definition and elimination of processes that altered the primary compositions of mantle-derived magmas. The correction for those processes then enables one to establish a common basis for comparing different data sets. In brief, crustally contaminated lavas have been identified (see section 5.3) and are not discussed regarding their mantle sources and melt- 
ing regime. Subsequently, chemical compositions of lavas were fractionation-corrected because the crystallization of mineral phases or the accumulation of minerals alter the composition of a melt significantly. The used fractionation correction scheme follows the approach of Klein and Langmuir [1987] and includes only lavas with $\mathrm{MgO}>5$ wt \%. Because fractionation histories of lavas with $\mathrm{MgO}<5 \mathrm{wt} \%$ are too complex in that a correction would lead to unreliable results, such lavas were not considered. However, all Arabian lavas were divided into 46 subgroups in
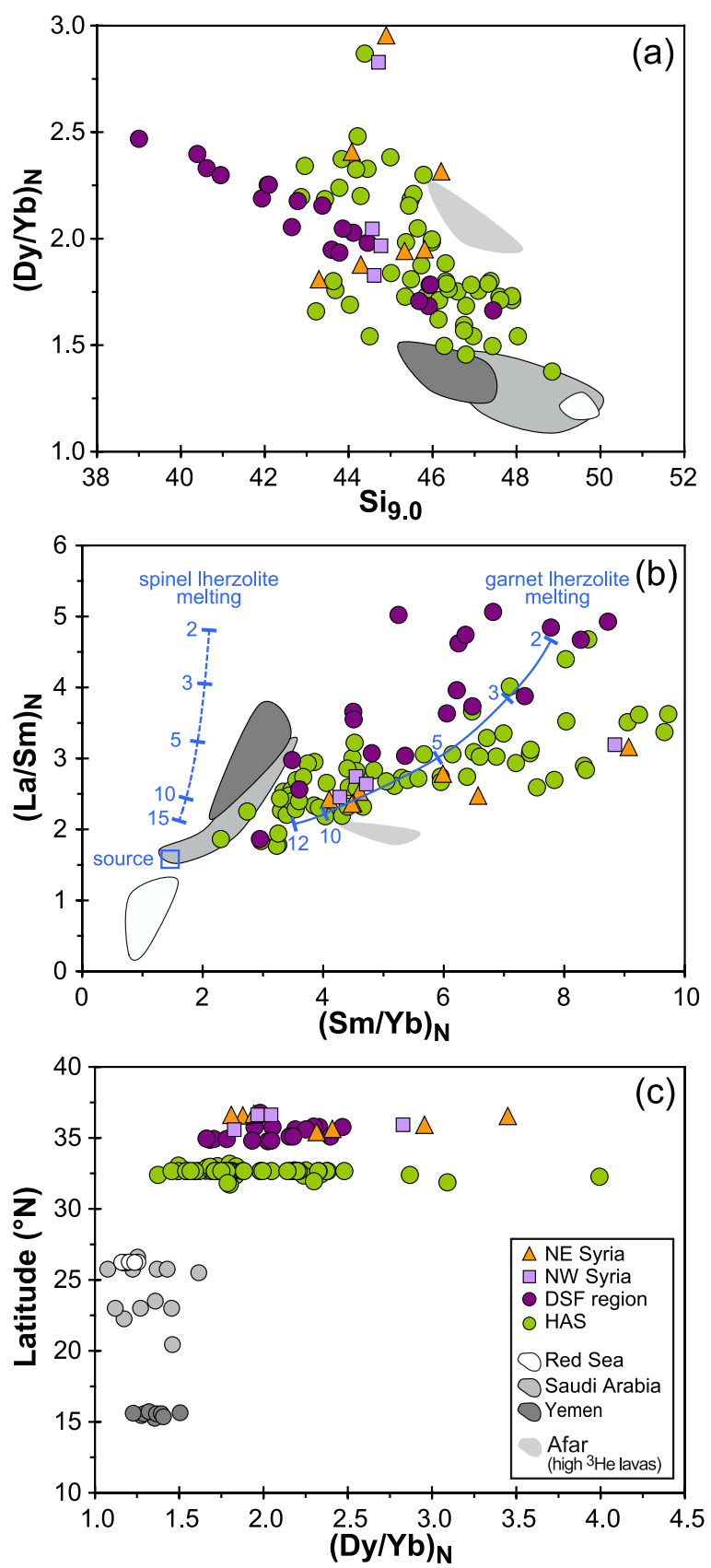

dependence of their spatiotemporal occurrence. The compositions of lavas subsequently were corrected along specific fractionation paths, which were defined by each of the subgroups, to compositions of $\mathrm{MgO}=9.0 \mathrm{wt} \%$ (subscript 9.0; this procedure is exemplary shown for three representative subsets of samples in Figure S1).

[12] Fractionation-corrected major element and olivine adjusted compositions (see caption of Figure 10 for olivine addition procedure) as well as chondrite-normalized (subscript N) REE ratios of crustally uncontaminated lavas, which were erupted simultaneously during the last $13 \mathrm{Ma}$ are plotted in Figures 3 and 4. For comparative purposes lavas from the Afar region with characteristically high ${ }^{3} \mathrm{He} /{ }^{4} \mathrm{He}$ ratios are also shown (compare Figure 5). Generally, the $\mathrm{Si}_{15}$ contents of the lavas are variable and negatively correlated with $\mathrm{Fe}_{15}$ (Figure $3 \mathrm{a}$ ). The highest $\mathrm{Si}_{15}$ concentrations can be observed in lavas from the Red Sea $(47-50 \mathrm{wt} \%)$ and lowest concentrations occur in the DSF group (down to 39 wt \%), whereas lavas from the remaining regions have $\mathrm{Si}_{15}$ between 42 and 48 wt \%. A well-defined positive correlation between $\mathrm{Ti}_{9.0}$ and $\mathrm{Fe}_{9.0}$ exists for the whole data set (Figure 3b). Notably, the Afar lavas have high $\mathrm{Fe}_{9.0}$ and $\mathrm{Ti}_{9.0}$ but are offset from the main trend to higher $\mathrm{Ti}_{9.0}$ values of about 4.5 wt $\%$ at $\mathrm{Fe}_{9.0}$ between 12 and 13 wt \%. In contrast, Red Sea lavas exhibit lowest $\mathrm{Fe}_{9.0}\left(11-7\right.$ wt \%) and $\mathrm{Ti}_{9.0}$ typically below 1 . Comparatively high $\mathrm{Na}_{9.0}$ concentrations (up to 4.7 wt \%) are observed for the DSF and HAS groups (Figure 3c), whereas Yemeni

Figure 4. Fractionation-corrected $\mathrm{Si}$ and chondritenormalized (subscript $\mathrm{N}$ ) rare earth element ratios of crustally uncontaminated lavas $\left(\mathrm{Ce} / \mathrm{Pb}>20 ;{ }^{143} \mathrm{Nd} /{ }^{144} \mathrm{Nd}\right.$ $>0.5128$ ) from the Arabian region: (a) $\mathrm{Si}_{9.0}$ versus (Dy/ $\mathrm{Yb})_{\mathrm{N}},(\mathrm{b})(\mathrm{Sm} / \mathrm{Yb})_{\mathrm{N}}$ versus $(\mathrm{La} / \mathrm{Sm})_{\mathrm{N}}$, and (c) latitude versus $(\mathrm{Dy} / \mathrm{Yb})_{\mathrm{N}}$. Exemplarily shown in Figure $4 \mathrm{~b}$ are melting curves for nonmodal batch melting of garnet (continuous) and spinel (dashed) lherzolites of a relative to a primitive mantle composition enriched mantle source. Source concentrations are $\mathrm{La}=2.29 \mathrm{ppm}, \mathrm{Sm}=$ $0.93 \mathrm{ppm}$, and $\mathrm{Yb}=0.55 \mathrm{ppm}$. Spinel lherzolite composition is $0.53 \mathrm{ol}, 0.17 \mathrm{cpx}, 0.27 \mathrm{opx}, 0.030 \mathrm{spi}$ with melting proportions $0.63 \mathrm{ol}, 0.20 \mathrm{cpx}, 0.11 \mathrm{opx}$, and $0.05 \mathrm{spi}$. Garnet lherzolite composition is $0.552 \mathrm{ol}, 0.202$ cpx, $0.212 \mathrm{opx}, 0.04$ grt with melting proportions $0.63 \mathrm{ol}$, $0.20 \mathrm{cpx}, 0.11 \mathrm{opx}$, and 0.05 grt. Distribution coefficients used are from Johnson [1998] for $\mathrm{Sm}_{\text {grt-melt }}$ and $\mathrm{Yb}_{\text {grt-melt }}$; otherwise, coefficients are from Kelemen et al. [1993]. Numbers give the melting degree in percent. Data sources are as in Figure 3, and chondrite values are from McDonough and Sun [1995]. 

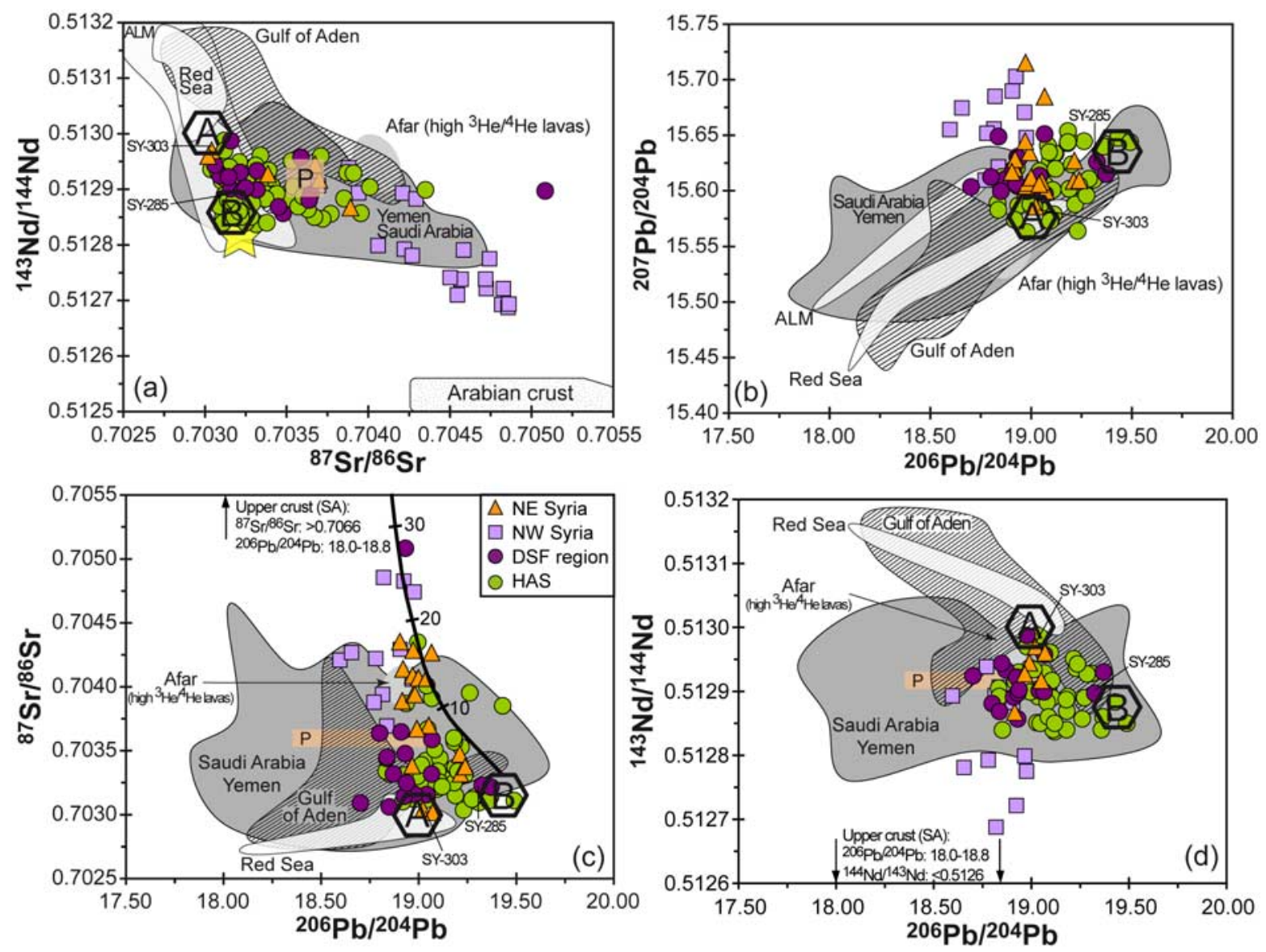

Figure 5. (a-d) $\mathrm{Sr}, \mathrm{Nd}$, and $\mathrm{Pb}$ isotope correlations of volcanic rocks from Syria. Note that crustally contaminated samples are also included in this diagram. Hexagons labeled " $A$ " and "B" indicate proposed mantle end-member compositions involved in Syrian volcanism, and SY-285 and SY-303 are representative lavas. The yellow star indicates compositions of lavas with ${ }^{206} \mathrm{~Pb} /{ }^{204} \mathrm{~Pb}>20.0$ from the East African Rift System [Furman et al., 2006], and the rectangle labeled "P" denotes the Afar plume composition proposed by Baker et al. [1996b]. The "Afar" field represents Afar plume lavas with high ${ }^{3} \mathrm{He} /{ }^{4} \mathrm{He}$ described by Marty et al. [1996]. Additionally shown in Figure $5 \mathrm{c}$ is a mixing curve between the proposed mantle end-member " $\mathrm{B}$ " ${ }^{87} \mathrm{Sr}{ }^{86} \mathrm{Sr}=0.7032, \mathrm{Sr}=493 \mathrm{ppm},{ }^{206} \mathrm{~Pb} /{ }^{204} \mathrm{~Pb}=19.5$, and $\mathrm{Pb}=2.5 \mathrm{ppm}$ ) and continental crustal compositions $\left({ }^{87} \mathrm{Sr} /{ }^{86} \mathrm{Sr}=0.7125, \mathrm{Sr}=326 \mathrm{ppm},{ }^{206} \mathrm{~Pb} /{ }^{204} \mathrm{~Pb}=18.7\right.$, and $\mathrm{Pb}=20 \mathrm{ppm}$ ) [Hegner and Pallister, 1989; Rudnick and Fountain, 1995]. Also shown are fields defined by lavas from Saudi Arabia and Yemen as well as from the Gulf of Aden region (including lavas from Gulf of Tadjoura and the Ardoukoba Rift) and the Red Sea and by samples representative of Arabian crust as well as by xenoliths from the Arabian lithospheric mantle (ALM). The Syrian data have been combined with published data from Altherr et al. [1990], Bertrand et al. [2003], Krienitz et al. [2006], Lustrino and Sharkov [2006], Shaw et al. [2003], Stein and Hofmann [1992], and Weinstein et al. [2006]. Other sources are as follows: Saudi Arabia (SA) and Yemen, Altherr et al. [1990], Baker et al. [1996a, 1997], Bertrand et al. [2003], Hegner and Pallister [1989], and Manetti et al. [1991]; Afar, Pik et al. [1999]; Red Sea, Altherr et al. [1988], Eissen et al. [1989], and Haase et al. [2000]; Gulf of Aden, Schilling et al. [1992]; Arabian crustal rocks, Jarrar et al. [2003] and Hegner and Pallister [1989]; Arabian lithospheric mantle xenoliths, Altherr et al. [1990], Blusztajn et al. [1995], and Henjes-Kunst et al. [1990].

and Saudi Arabian lavas have variable but slightly lower contents. Lavas from NW and NE Syria show $\mathrm{Na}_{9.0}$ contents scattering around 3 wt \%, and samples from the Afar and the Red Sea have $\mathrm{Na}_{9.0}$ constantly $<3$ wt \% (Figure 3c). A general north-to-south increase in $\mathrm{Si}_{9.0}$ and $\mathrm{Al}_{9.0}$ accompanied by decreasing $\mathrm{Fe}_{9.0}$ and $\mathrm{Ti}_{9.0}$ of the Arabian lavas can be noticed (Figures 3d-3f).
[13] In all Arabian lavas $\mathrm{Si}_{9.0}$ and $(\mathrm{Dy} / \mathrm{Yb})_{\mathrm{N}}$ are negatively correlated (Figure 4a). Syrian (NE, NW and DSF groups) and HAS lavas show largest variations in $(\mathrm{Dy} / \mathrm{Yb})_{\mathrm{N}}$ ranging from 3 to 1.5 and marginally overlapping with the upper end of the range spanned by lavas from Yemen and Saudi Arabia (1.5-1.2). Red Sea lavas with the highest $\mathrm{Si}_{9.0}$ have comparably low $(\mathrm{Dy} / \mathrm{Yb})_{\mathrm{N}}$ of $\sim 1.2$ and 
$(\mathrm{Dy} / \mathrm{Yb})_{\mathrm{N}}$ ratios of Afar samples scatter around 2.2 being higher than the rest of the Arabian but similar to NE, NW and DFS Syrian groups and HAS lavas. $(\mathrm{Sm} / \mathrm{Yb})_{\mathrm{N}}$ and $(\mathrm{La} / \mathrm{Sm})_{\mathrm{N}}$ are generally positive correlated (Figure 4b). The largest range is, in turn, displayed by NE, NW and DSF lavas as well as by the HAS lavas with highest values of about 10 and 5 for $(\mathrm{Sm} / \mathrm{Yb})_{\mathrm{N}}$ and $(\mathrm{La} / \mathrm{Sm})_{\mathrm{N}}$, respectively. In contrast, Red Sea volcanics typically show low ratios scattering around 1. An overall southward decreasing trend is observed when REE ratios are plotted versus latitude (Figure 4c).

\section{3. $\mathrm{Sr}, \mathrm{Nd}$, and $\mathrm{Pb}$ Isotopes}

[14] Syrian lavas define a rough triangular shaped field between ${ }^{87} \mathrm{Sr} /{ }^{86} \mathrm{Sr}$ and ${ }^{143} \mathrm{Nd} /{ }^{144} \mathrm{Nd}$ compositions of 0.7030 and 0.5130 (designated as endmember A), and 0.7032 and 0.51287 (designated as end-member B) and crustal compositions characterized by high $\mathrm{Sr}$ and low $\mathrm{Nd}$ isotopic compositions (Figure 5a). Interestingly, the majority of the HAS and DSF group lavas lie on a negative correlation between end-members A (represented by sample SY-285) and B (represented by sample SY-303), whereas several lavas from all four groups are offset from this main trend having intermediate $\mathrm{Nd}$ isotopic compositions but ${ }^{87} \mathrm{Sr}{ }^{86} \mathrm{Sr}$ significantly higher than 0.7033 . Especially lavas from NW Syria have much higher Sr and lower $\mathrm{Nd}$ isotope ratios than the rest of the Syrian samples (Figure 5a). Apart from several lavas from the NW group Syrian lavas overlap with volcanic rocks from Yemen and Saudi Arabia and also with xenolith compositions representative for Arabian lithospheric mantle. However, volcanic rocks of the Gulf of Aden region generally show a trend to higher ${ }^{143} \mathrm{Nd} /{ }^{144} \mathrm{Nd}$ compared to the Syrian samples whereas Afar lavas have significantly higher ${ }^{87} \mathrm{Sr} /{ }^{86} \mathrm{Sr}$ and lower ${ }^{207} \mathrm{~Pb} /{ }^{204} \mathrm{~Pb}$ (Figure 5).

[15] All Syrian lavas have ${ }^{206} \mathrm{~Pb} /{ }^{204} \mathrm{~Pb}$ between 18.60 and 19.50 , which is a much narrower range than the data for lavas from other Afro-Arabian regions (Figure $5 \mathrm{~b}$ ). In contrast, significant variation occurs in ${ }^{207} \mathrm{~Pb} /{ }^{204} \mathrm{~Pb}$ with the NW group and two NE Syrian lavas have the highest ${ }^{207} \mathrm{~Pb} /{ }^{204} \mathrm{~Pb}$ for a given ${ }^{206} \mathrm{~Pb} /{ }^{204} \mathrm{~Pb}$. Interestingly, the high ${ }^{207} \mathrm{~Pb} /{ }^{204} \mathrm{~Pb}$ ratios are associated with low $\mathrm{Ce} / \mathrm{Pb}$ values and those lavas define trends to crustal compositions (Figure 5). Variations in ${ }^{208} \mathrm{~Pb} /{ }^{204} \mathrm{~Pb}$ are relatively small and a positive correlation between ${ }^{208} \mathrm{~Pb} /{ }^{204} \mathrm{~Pb}$ and ${ }^{206} \mathrm{~Pb} /{ }^{204} \mathrm{~Pb}$ in Syrian lavas is similar to lavas from southern Arabia (not shown). The Syrian volcanics overlap with samples from Saudi Arabia, Yemen, the Gulf of Aden and the Red Sea, but some have significantly higher ${ }^{207} \mathrm{~Pb} /{ }^{204} \mathrm{~Pb}$. Generally, the HAS group shows slightly higher ${ }^{206} \mathrm{~Pb} /{ }^{204} \mathrm{~Pb}$ compared to the remaining Syrian groups (Figure 5b). In plots of ${ }^{206} \mathrm{~Pb} /{ }^{204} \mathrm{~Pb}$ versus ${ }^{87} \mathrm{Sr} /{ }^{86} \mathrm{Sr}$ and ${ }^{143} \mathrm{Nd} /{ }^{144} \mathrm{Nd}$ many Syrian lavas show a large range of $\mathrm{Sr}$ and $\mathrm{Nd}$ isotopic compositions at nearly constant ${ }^{206} \mathrm{~Pb} /{ }^{204} \mathrm{~Pb}$ between 18.80 and 19.10 (Figures $5 \mathrm{c}$ and 5d). However, at relatively low $\mathrm{Sr}$ and high $\mathrm{Nd}$ isotope ratios of $<0.7033$ and $>0.5128$, respectively, we find a variation of the ${ }^{206} \mathrm{~Pb} /{ }^{204} \mathrm{~Pb}$ between 18.8 and 19.5. The Syrian lavas with the most radiogenic ${ }^{143} \mathrm{Nd} /{ }^{144} \mathrm{Nd}$ of $\sim 0.5130$ (end-member $\mathrm{A}$ ) have ${ }^{206} \mathrm{~Pb} /{ }^{204} \mathrm{~Pb}$ ratios of $\sim 19.0$, whereas lavas representing end-member $\mathrm{B}$ have the highest ${ }^{206} \mathrm{~Pb} /{ }^{204} \mathrm{~Pb}$ of $\sim 19.5$. Again the Syrian lavas overlap with compositions displayed by samples from southern Arabia (Figure 5d).

\section{Discussion}

\subsection{Age Dating: Comparison With Previous Studies}

[16] The thin lava flows south of Aleppo yield an Ar-Ar age of about 19.4 Ma (Figure 6) compared to previous K-Ar ages of 16.7 to $18.0 \mathrm{Ma}$ [Mouty et al., 1992]. An about $300 \mathrm{~m}$ thick lava succession further north close to the Turkish border was dated at 11.1 to $12.2 \mathrm{Ma}$ showing similar ages to recently dated lavas further east near the Euphrates river with an Ar-Ar age of $8.8 \mathrm{Ma}$ [Demir et al., 2007]. The NE Syrian volcanism is much younger than in the NW and our ages of 3.9 to $0.4 \mathrm{Ma}$ agree well with K-Ar ages of 2.9 to $0.9 \mathrm{Ma}$ [Sharkov et al., 1998] and Ar-Ar ages of 2.7 to $0.1 \mathrm{Ma}$ for lavas erupted in the Euphrates region [Demir et al., 2007]. One sample from the Al Ghab graben has an age of $1.8 \mathrm{Ma}$ consistent with previously published K-Ar ages (1.9 to 1.5 Ma [Sharkov et al., 1998]). Two lavas from the Jebel Barshin lava plateau near the Dead Sea Fault gave ages of 5.1 to $5.3 \mathrm{Ma}$ (Figure 6), in agreement with most $(\mathrm{n}=18)$ previously dated samples ranging between 6.3 and 4.9 Ma [Butler et al., 1997; Mouty et al., 1992; Sharkov et al., 1994, 1998]. However, six samples from the Homs region dated by Mouty et al. [1992] gave much older K-Ar ages of 120 to $90 \mathrm{Ma}$ which may be unreliable because in two cases other samples from the same locality yielded younger ages of 5.6 Ma and 14.6 Ma [Mouty et al., 1992]. The new ${ }^{40} \mathrm{Ar} /{ }^{39} \mathrm{Ar}$ ages for lavas from the HAS volcanic field in southern Syria suggest a relatively 


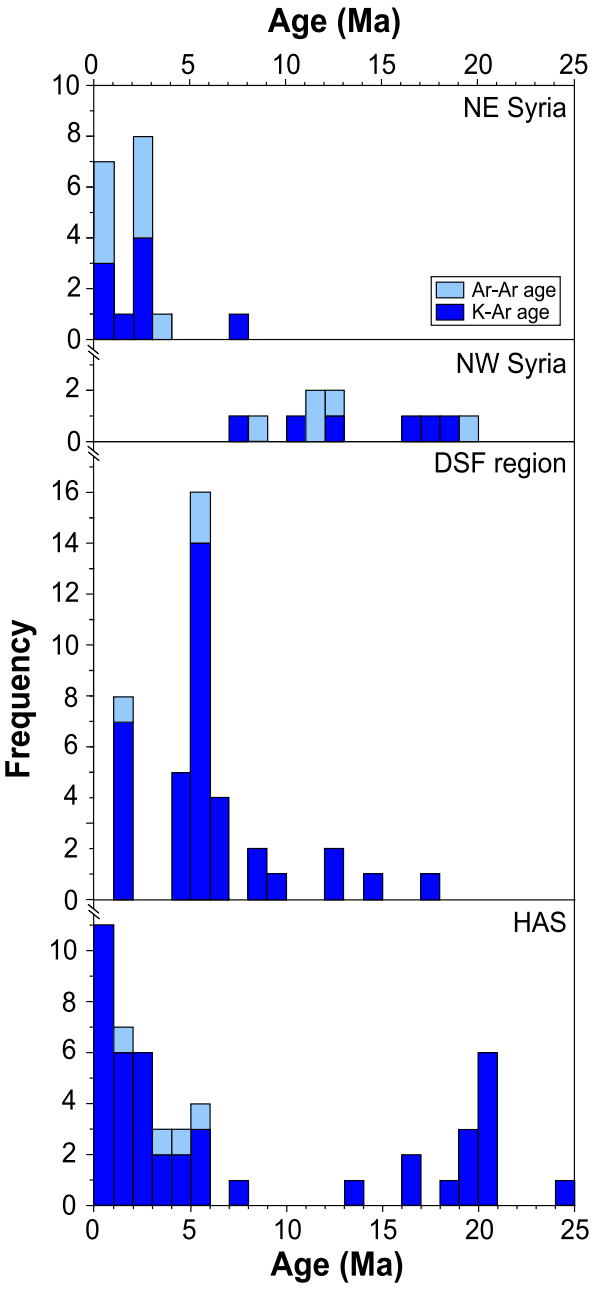

Figure 6. Histograms of K-Ar (dark blue) and Ar-Ar (light blue) ages of lavas from the main volcanic Syrian regions. Data sources are this work and from Butler et al. [1997], Demir et al. [2007], Giannérini et al. [1988], Mouty et al. [1992], and Sharkov et al. [1994, 1998].

young age of less than 5.5 Ma compared to lavas from the Jordanian part which range between 24 and 0.3 Ma [e.g., Ilani et al., 2001; Sharkov et al., 1994; Tarawneh et al., 2000]. Thus, Krienitz et al. [2007] reported ${ }^{40} \mathrm{Ar}{ }^{39} \mathrm{Ar}$ ages for lavas recovered from a stratigraphic section within the HAS volcanic field showing that lavas from the lower part of this section $(\sim 1070 \mathrm{~m}$ altitude $)$ and from the uppermost part $(\sim 1760 \mathrm{~m}$ altitude) yield ages between 4.2 and $3.3 \mathrm{Ma}$, respectively. Consequently, about $700 \mathrm{~m}$ of the plateau erupted in less than $1 \mathrm{Ma}$ and thus with extrusion rates comparable to other flood basalt plateaus (e.g., Ethiopia [Hofmann et al., 1997]). The new ages indicate that abundant volcanism occurred in Syria within the last $21 \mathrm{Ma}$, i.e., later than the prerift flood basalt volcanism in Ethiopia and Yemen at 31-25 Ma but contempora- neous with the younger volcanic phases of the AfroArabian region [e.g., Ukstins et al., 2002]. Each region in Syria appears to have been volcanically active in distinct periods that partly overlap but with significant time gaps in between. Importantly, no time progression of the volcanic activity is observed within Syria.

\subsection{Relationship of Volcanic Activity and Tectonic Events}

[17] As discussed above the spatiotemporal distribution of volcanism in Syria may be related to either regional tectonic processes affecting the region or to inflow of plume material from the south. The oldest volcanic phase in Syria occurred between 21 and $16 \mathrm{Ma}$ in the HAS and in NW Syria coinciding with the first phase of movement along the Dead Sea Fault (Figures 6 and 7). The HAS lies close to two graben structures of which at least the southern Sirhan graben formed during the late Oligocene to mid-Miocene [Almond, 1986; Schattner et al., 2006, Figure 1]. However, it appears unlikely that this small rift thinned the lithosphere sufficiently to cause voluminous partial melting of the mantle beneath the HAS as the thickness of the lithosphere in the whole region is about $80 \mathrm{~km}$ [Mohsen et al., 2006]. Rather, the beginning volcanism at the HAS has been interpreted to reflect the arrival of hot mantle underneath this region [Krienitz et al., 2007], with melting and magma ascent possibly being enhanced by extensional tectonics.

[18] In NW Syria volcanism at 12 to 9 Ma could be related to a change in the lithospheric stress field and extension caused by the initiation of seafloor spreading producing the Gulf of Aden [e.g., Hempton, 1987]. However, the Aleppo region in NW Syria lies close to the Bitlis suture where compression occurred in the Miocene rather than extension [e.g., Hempton, 1987, Figure 1]. Thus, the younger alkaline volcanism in northern Syria and southern Turkey is more likely related to slab break-off of the subducting slab beneath the Bitlis suture at 11 to $10 \mathrm{Ma}$ [Faccenna et al., 2006]. Asthenospheric upwelling above the sinking slab could generate the NW Syrian magmas due to adiabatic decompression [Keskin, 2003]. In agreement with our suggestion are studies about southern Turkey lavas from the Karacadag volcano [Pearce et al., 1990; Sen et al., 2004] which showed on the basis of major and trace element as well as isotopic compositions that these lavas were generated from a sublithospheric, slightly 


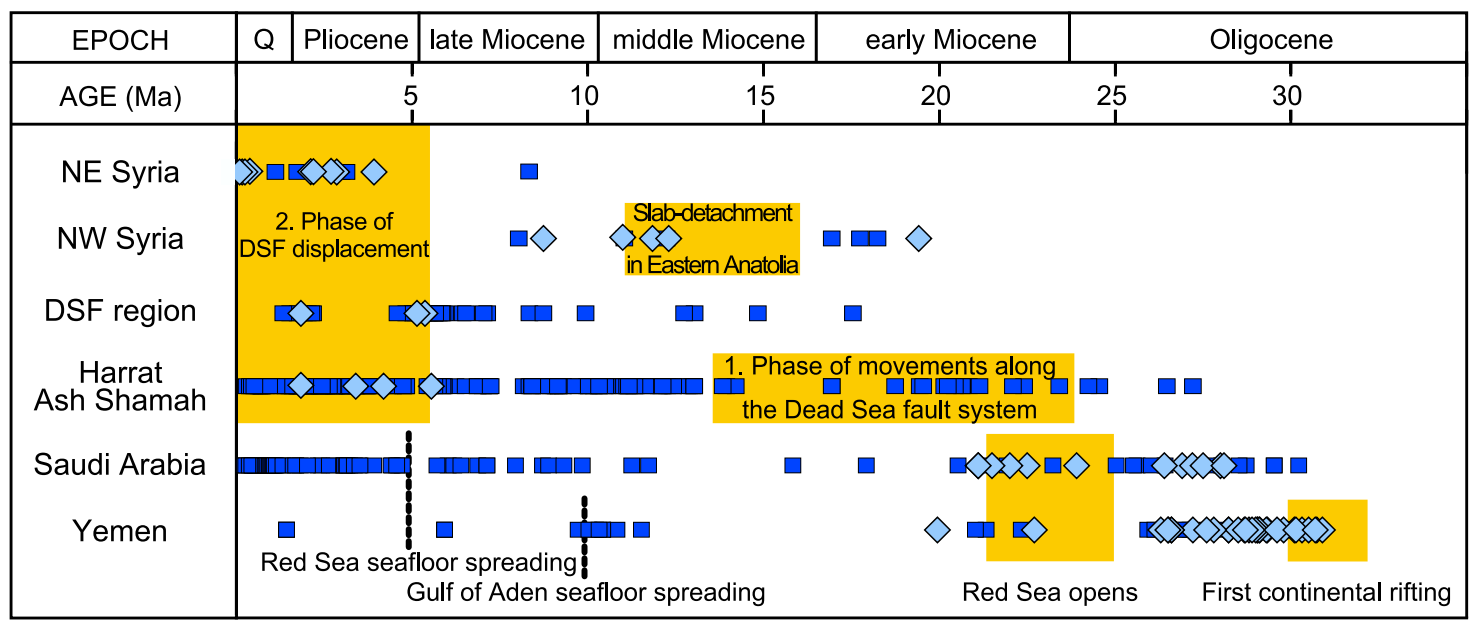

Figure 7. Compilation of K-Ar (dark blue rectangles) and $\operatorname{Ar}-\operatorname{Ar}$ (light blue diamonds) ages of lavas from Arabia and major plate tectonic events. Data sources are as follows: Syria, this work and as in Figure 6; Harrat Ash Shamah (Jordan), Barberi et al. [1980], Tarawneh et al. [2000], Ilani et al. [2001], and Shaw et al. [2003]; Saudi Arabia, Altherr et al. [1990], Camp and Roobol [1989], Camp et al. [1991], du Bray et al. [1991], Hegner and Pallister [1989], Pallister [1987], and Sebai et al. [1991]; Yemen, Baker et al. [1996a] and Manetti et al. [1991].

trace element enriched mantle source with melt generation under garnet-facies conditions. However, asthenospheric upwelling due to a sinking slab is supported by the observed uplift of the Aleppo region and negative seismic velocity anomalies beneath the Bitlis-Zagros collisional belt indicating relatively hot material in the upper mantle [e.g., Faccenna et al., 2006].

[19] In the last $6 \mathrm{Ma}$ widespread volcanism occurred in Syria along the Dead Sea Fault but also in relatively stable intraplate areas (HAS, NW and NE Syria) contemporaneous with activity at several large volcanic fields along the Red Sea coast [e.g., Demir et al., 2007; Giannérini et al., 1988; Mouty et al., 1992; Sharkov et al., 1994, 1998, Figures 1 and 6]. This time corresponds to the second phase of movements along the Dead Sea Fault and the commencing ocean floor spreading in the Red Sea [Girdler, 1990, Figure 7]. Although volcanism may be induced by lithospheric extension due to movements along the Dead Sea Fault and the Euphrates Graben, the magma generation in areas distant from extensional tectonic features requires the presence of hot mantle material beneath the Arabian region; that is, the higher potential temperature of the mantle allows voluminous melting even beneath relatively thick lithosphere. Interestingly, the magmatic activity in the northeastern parts of Syria is restricted to the youngest phase (4 to $0 \mathrm{Ma}$ ) and thus may indicate the northward migration of the hot mantle material (Figures 6 and 7). We will use chemical and $\mathrm{Sr}, \mathrm{Nd}$, and $\mathrm{Pb}$ isotope compositions of the lavas to test this model further, to investigate the melting regime and to define mantle sources contributing to Syrian magmas.

\subsection{Crustal Contamination}

[20] Since magmas in continental regions are frequently affected by crustal assimilation, these contamination effects must be eliminated before the primary mantle source characteristics can be evaluated. We use the $\mathrm{Ce} / \mathrm{Pb}$ and $\mathrm{Nb} / \mathrm{Th}$ ratios of lavas to identify crustally contaminated magmas because mid-ocean ridge and ocean island basalts have average $\mathrm{Ce} / \mathrm{Pb}$ ratios of $25 \pm 5$ [Hofmann et al., 1986] and $\mathrm{Nb} / \mathrm{Th}$ ratios of 10-20 [Hofmann, 2003] which are thus characteristic for lavas derived from the Earth's mantle (Figure 8). In contrast, continental crustal rocks exhibit lower $\mathrm{Ce} / \mathrm{Pb}$ and $\mathrm{Nb} / \mathrm{Th}$ ratios with averages of $\sim 4$ and 3 , respectively [Rudnick and Fountain, 1995]. The Syrian crust is composed of thick sediments covering Proterozoic rocks similar to those from Jordan and Saudi Arabia [e.g., Snyder et al., 1993]. We find roughly triangular variations of $\mathrm{Ce} / \mathrm{Pb}$ and $\mathrm{Nb} / \mathrm{Th}$ versus ${ }^{206} \mathrm{~Pb} /{ }^{204} \mathrm{~Pb}$ where samples reflecting end-members $\mathrm{A}$ and $\mathrm{B}$ have relatively high $\mathrm{Ce} / \mathrm{Pb}$ and $\mathrm{Nb} / \mathrm{Th}$ typical of uncontaminated magmas (Figure 8). Interestingly, end-member A lavas have slightly higher $\mathrm{Ce} / \mathrm{Pb}$ and $\mathrm{Nb} / \mathrm{Th}$ than end-member $\mathrm{B}$ lavas, whereas both end-member compositions overlap the range suggested for oceanic magmas. Thus, these two end-members represent mantle compositions, whereas lavas trending to lower $\mathrm{Ce} / \mathrm{Pb}$ and $\mathrm{Nb} / \mathrm{Th}$ ratios are contaminated by crustal material. 

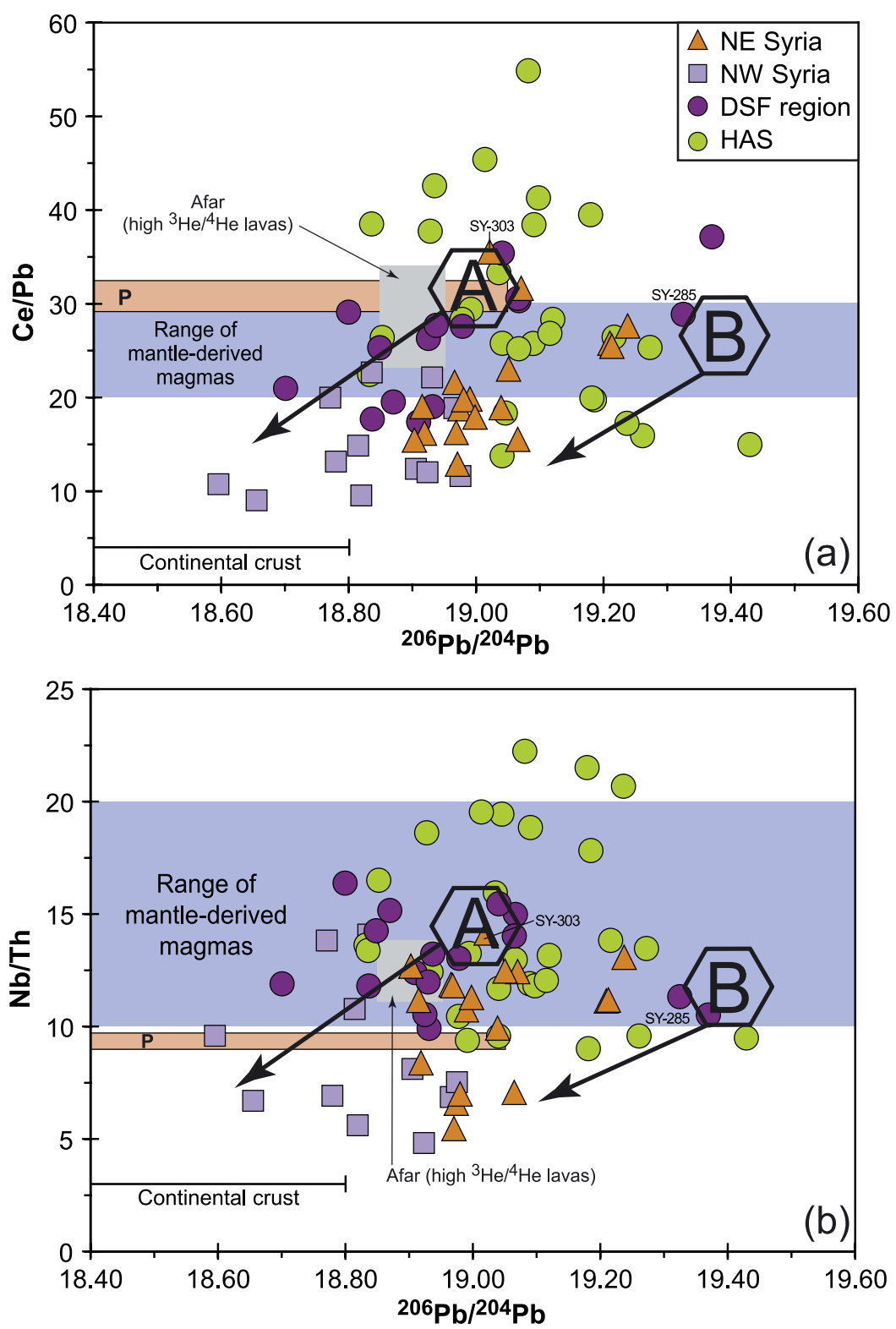

Figure 8. Variations of (a) $\mathrm{Ce} / \mathrm{Pb}$ and (b) $\mathrm{Nb} / \mathrm{Th}$ versus ${ }^{206} \mathrm{~Pb} /{ }^{204} \mathrm{~Pb}$. Arrows indicate possible crustal contamination directions, and the lilac fields are defined on the basis of studies of oceanic basalts [Hofmann et al., 1986] which are not affected by continental crustal contamination. Data sources are as in Figure 3; crustal trace element data are from Rudnick and Fountain [1995].

In contrast, several lavas from the HAS group deviate from the oceanic range to higher values. This observation can be explained by varying degrees of melt because $\mathrm{Pb}$ is more compatible than Ce during mantle melting [Sims and DePaolo, 1997] and small degree melts therefore have high $\mathrm{Ce} / \mathrm{Pb}$ in lavas. However, Proterozoic continental crustal rocks from Saudi Arabia have ${ }^{206} \mathrm{~Pb} /{ }^{204} \mathrm{~Pb}$ of 18.0 to 18.8 [Hegner and Pallister, 1989] in agreement with the trend of contaminated Syrian lavas to low $\mathrm{Ce} / \mathrm{Pb}$ and ${ }^{206} \mathrm{~Pb} /{ }^{204} \mathrm{~Pb}$ (Figure 8). Furthermore, many of the Syrian lavas also have $\mathrm{Sr}$ isotope ratios $\gg 0.7033$ which also suggests crustal contamination which is most notable in the trend of NW Syrian lavas toward upper crustal rocks with high ${ }^{87} \mathrm{Sr} /{ }^{86} \mathrm{Sr}$ and low ${ }^{143} \mathrm{Nd} /{ }^{144} \mathrm{Nd}$ [Jarrar et al., 2003, Figure 5]. Binary mixing calculations between end-member $\mathrm{B}\left({ }^{206} \mathrm{~Pb} /{ }^{204} \mathrm{~Pb}=19.45\right.$; $\left.{ }^{87} \mathrm{Sr} /{ }^{86} \mathrm{Sr}=0.7032\right)$ and crustal compositions reveal that contamination of up to $30 \%$ of continental crust can produce the observed $\mathrm{Sr}$ isotopic range in the Syrian lavas (Figure 5c). This result agrees with the calculations of Shaw et al. [2003] who showed that lavas from the Jordanian part of the HAS field 
have assimilated up to $20 \%$ of continental crustal material.

[21] Because postmagmatic alteration/open system processes are able to change the $\mathrm{Sr}$ isotopic compositions of lavas because of mobile behavior of $\mathrm{Sr},{ }^{87} \mathrm{Sr} /{ }^{86} \mathrm{Sr}$ were disregarded for defining crustal contaminated lavas and instead ${ }^{143} \mathrm{Nd} /{ }^{144} \mathrm{Nd}$ and $\mathrm{Ce} / \mathrm{Pb}$ ratios were used. Samples with ${ }^{143} \mathrm{Nd} /{ }^{144} \mathrm{Nd}$ $<0.5128$ and/or with $\mathrm{Ce} / \mathrm{Pb}$ ratios $<20$ were assumed being contaminated and remained out of further consideration (Figures 5a and 8a). Volcanic samples lacking isotope and trace element data were also rejected because contamination criteria could not be applied. One exception concerned lavas from the Saudi Arabian Harrats for which available trace element and isotope analyses are rare or completely lacking. Nonetheless these lavas were included into discussion, because there is petrologic and geologic evidence for the role of crustal contamination being minor [Camp et al., 1991] and because Camp et al. [1991] noticed that the low $\mathrm{Sr}$ isotopic compositions [Baubron and Maury, 1980] from several basaltic and intermediate lavas from Harrat Khaybar suggest insignificant crustal contamination.

\subsection{Melting Regime Beneath Arabia}

[22] Melting experiments have shown that the $\mathrm{Si}$ and $\mathrm{Fe}$ contents of melts are largely independent of the temperature of melting, but strongly depend on pressure and that decreasing pressures lead to increasing $\mathrm{SiO}_{2}$ and decreasing $\mathrm{Fe}$ concentrations in melts [Hirose and Kushiro, 1993; Jaques and Green, 1980, Figure 3a]. In the Red Sea Rift region the melting processes and magma compositions could vary because of (1) variable lithospheric thickness at constant mantle temperature, (2) variable temperature at constant lithospheric thickness, or (3) variable temperature and variable lithospheric thickness. The negative correlation between $\mathrm{Si}_{15}$ and $\mathrm{Fe}_{15}$ concentrations of the Arabian lavas is consistent with the assumption that compositional variability is caused by variable melting pressures (Figure 3a). Negative correlations between $\mathrm{Si}$ and $\mathrm{Fe}$ have also been observed in Tertiary flood basalt samples from the North Atlantic Province [Fram and Lesher, 1993; Scarrow et al., 2000] and in lavas from ocean islands or at mid-ocean ridges [e.g., Langmuir et al., 1992]. These correlations have been attributed to compositional variations generated by melt formation over a range of depths. The Red Sea lavas with high $\mathrm{Si}$ contents and low Fe were generally produced at relatively shallow depths ( 1-2 GPa, $\sim 30-60 \mathrm{~km})$, whereas the lowest Si coupled with high $\mathrm{Fe}$ concentrations in Syrian groups and HAS lavas indicate relatively high melting pressures $(>2 \mathrm{GPa}$, Figures $3 \mathrm{a}$ and 10$)$. Consequently, lavas from the remaining Arabian regions with intermediate $\mathrm{Si}$ and $\mathrm{Fe}$ contents formed at intermediate pressures.

[23] The positive correlation between $\mathrm{Fe}_{9.0}$ and $\mathrm{Ti}_{9.0}$ (Figure 3b) implies decreasing degrees of partial melting with increasing pressures, i.e., a dependence of partial melting on lithospheric thickness (case 1) rather than on variable mantle temperatures at constant lithospheric thickness (case 2) which should lead to a negative correlation between $\mathrm{Fe}$ and $\mathrm{Ti}$. With changing mantle temperatures and lithospheric thickness (case 3) the magma compositions should not cause any correlation between $\mathrm{Fe}$ and $\mathrm{Ti}$ because different degree melts would be generated at different pressures. Consequently, the variation of mantle melting reflected by the basalt compositions depends on nonuniform thinning of the lithosphere related to the rifting processes of the Red Sea region but the mantle temperature is relatively constant. The correlations between $\mathrm{Si}, \mathrm{Ti}$, and $\mathrm{Fe}$ in the Arabian and Red Sea lavas therefore suggest that increasing degrees of melting are associated with decreasing pressures in a pressure-controlled melting regime, i.e., by variable lithospheric thickness (Figure 3).

[24] The $(\mathrm{La} / \mathrm{Sm})_{\mathrm{N}}$ and $(\mathrm{Sm} / \mathrm{Yb})_{\mathrm{N}}$ ratios of northern Arabian lavas show large variations and trend to higher ratios compared to Saudi Arabian, Yemen and Afar lavas with low $(\mathrm{La} / \mathrm{Sm})_{\mathrm{N}}(<4)$ and $(\mathrm{Sm} /$ $\mathrm{Yb})_{\mathrm{N}}(<6)$ (Figure 4b). These differences may reflect distinct mantle source compositions and/or variations in the degree and depth of melting. The large range of REE ratios of the Arabian lavas indicate variable degrees of partial melting with residual garnet in the source regions of the Syrian and HAS lavas and thus the generation from garnet peridotite at high pressures (Figure 4). Krienitz et al. [2007] have shown that the REE ratios in the Syrian HAS lavas are compatible with melting of mantle sources containing variable amounts of garnet at depths of $\sim 100 \mathrm{~km}$ (see Figure 10). In contrast, lavas from southern Arabia and Afar have lower $(\mathrm{Sm} / \mathrm{Yb})_{\mathrm{N}}$ and $(\mathrm{Dy} / \mathrm{Yb})_{\mathrm{N}}$ along with higher $\mathrm{Al}_{2} \mathrm{O}_{3}$ concentrations than northern Arabian lavas indicating less garnet in their sources. Baker et al. [1997] proposed that the REE patterns of Yemeni lavas are produced by mixing of small melt fractions generated in a predominantly garnet perido- 
tite facies mantle with larger degree melts of a spinel peridotite mantle source. We conclude that the northern Arabian magmas form by variable degree of melting of garnet peridotite mantle whereby the basalts in the south formed from garnet and spinel peridotite, i.e., shallower in the mantle (Figure $4 \mathrm{~b}$ ). The variation of the melting degree between $\sim 1$ and $6 \%$ partial melting implies temperature variations in the mantle of $<50^{\circ} \mathrm{C}$ [Baker and Stolper, 1994] in agreement with our conclusion of relatively constant mantle temperatures (Figure 3b).

[25] The low $\mathrm{Si}_{9.0}$ contents in lavas are coupled with high $(\mathrm{Dy} / \mathrm{Yb})_{\mathrm{N}}$ ratios confirming the relation between the extent and depths of melt formation (Figures $3 \mathrm{~b}$ and $4 \mathrm{a}$ ). The commencing melting process therefore probably took place at greater depths with minor degrees of melting in northern Arabia, i.e., in Syria, Israel and Jordan, compared to the south and the Red Sea region. This assumption agrees with the conclusions of Shaw et al. [2003] that melt formation in Jordan took place at deeper levels than in Yemen.

\subsection{Subcontinental Lithosphere as Possible Source for Arabian Magmas?}

[26] Several authors argued that the Arabian magmas formed largely from metasomatized subcontinental lithospheric mantle sources because of (1) the abundance of lavas with radiogenic $\mathrm{Pb}$ isotopes in Arabia [Bertrand et al., 2003]; (2) the apparent contribution of spinel peridotite melts to the magmas [Baker et al., 1997; Shaw et al., 2003]; (3) the similarities in isotopic and incompatible element signatures of Yemeni lavas and amphibole-bearing lithospheric mantle xenoliths [Baker et al., 1998]; and (4) the relative depletion of $\mathrm{K}, \mathrm{Rb}$, and $\mathrm{Ba}$ in the magmas attributed to residual amphibole or phlogopite in the melting zone [Weinstein et al., 2006]. The stability of amphibole or phlogopite in the upper mantle is restricted to the subcontinental lithospheric mantle [e.g., Harlow and Davies, 2004] and the presence of a volatile-rich source in the Arabian lithosphere could explain the extensive melting [e.g., Gallagher and Hawkesworth, 1992]. If true, then melting models, which were developed on the basis of anhydrous mantle assemblages, will be inappropriate to explain volcanism.

[27] However, it appears unlikely that the Arabian subcontinental lithospheric mantle represents the magma source with the radiogenic $\mathrm{Pb}$ isotopes (source B) because similar magmas occur in the
Gulf of Aden which is underlain by oceanic lithosphere (Figures 1 and 5). Rather, this mantle source must reside in the asthenosphere which explains its wide abundance and in fact, source B bears some resemblance to the globally occurring source FOZO [Hart et al., 1992; Hauri et al., 1994]. Our REE model does not require melting of spinel peridotite and rather, all of the melts from northern Arabia formed from garnet peridotite, i.e., from mantle deeper than perhaps $80 \mathrm{~km}$ (Figure $4 \mathrm{~b})$ which is consistent with the thick lithosphere determined by seismic studies [e.g., Hansen et al., 2006, 2007; Park et al., 2008]. The observed variation in $(\mathrm{La} / \mathrm{Sm})_{\mathrm{N}}$ probably reflects differences in the enrichment of the mantle, i.e., different source compositions consistent with the variations of the radiogenic isotopes. The composition of the Arabian lithosphere is relatively well known and numerous studies of mantle xenoliths indicated variable incompatible element as well as $\mathrm{Sr}, \mathrm{Nd}$, and $\mathrm{Pb}$ isotopic compositions [Altherr et al., 1990; Blusztajn et al., 1995; Henjes-Kunst et al., 1990, Figure 5]. Most peridotites cannot represent sources for the basalts because of too low incompatible element concentrations, too high ${ }^{87} \mathrm{Sr} /{ }^{86} \mathrm{Sr}$ and too low ${ }^{206} \mathrm{~Pb} /{ }^{204} \mathrm{~Pb}$ (Figure 5). Only few, relatively incompatible element-enriched peridotites have isotopic compositions with ${ }^{87} \mathrm{Sr} /{ }^{86} \mathrm{Sr}$ of $\sim 0.7035$ and ${ }^{206} \mathrm{~Pb} /{ }^{204} \mathrm{~Pb}$ of $\sim 19.0$ [Baker et al., 1998] similar to some alkaline basalts but the $\mathrm{Pb}$ isotope ratios are too low to represent the enriched source $\mathrm{B}$ and the ${ }^{87} \mathrm{Sr} /{ }^{86} \mathrm{Sr}$ ratios are too high to represent source A. Although there may exist lithologies like underplated basalts or cumulates that potentially could reflect the isotopic compositions of the Syrian lavas neither geochemical nor isotope data have been determined so far. On the basis of the available mantle xenolith studies we conclude that no peridotites with radiogenic isotope compositions similar to the basalts are known from the Arabian subcontinental lithosphere. Furthermore, clinopyroxene is the most important reservoir for the rare earth elements and $\mathrm{Zr}$ in mantle peridotite [Garrido et al., 2000] and clinopyroxene from the Arabian enriched hydrous spinel lherzolites have very low $\mathrm{Zr} / \mathrm{Sm} \leq 1$ [Baker et al., 1998] possibly reflecting metasomatism by a hydrous fluid. However, the Arabian basalts have high $\mathrm{Zr} / \mathrm{Sm}>20$ reflecting their generation from a different enriched source deeper than the lithospheric spinel lherzolites. The Syrian basalts with the highest $(\mathrm{La} / \mathrm{Sm})_{\mathrm{N}}$ and relatively low ${ }^{143} \mathrm{Nd} /{ }^{144} \mathrm{Nd}$ (source B) have the lowest $\mathrm{K} / \mathrm{La}$ of $\sim 140$ whereas the basalts with higher ${ }^{143} \mathrm{Nd} /{ }^{144} \mathrm{Nd}$ and lower $(\mathrm{La} / \mathrm{Sm})_{\mathrm{N}}$ have $\mathrm{K} /$ La up to 300 (Figure 9). The depletion of $\mathrm{K}, \mathrm{Rb}$, 

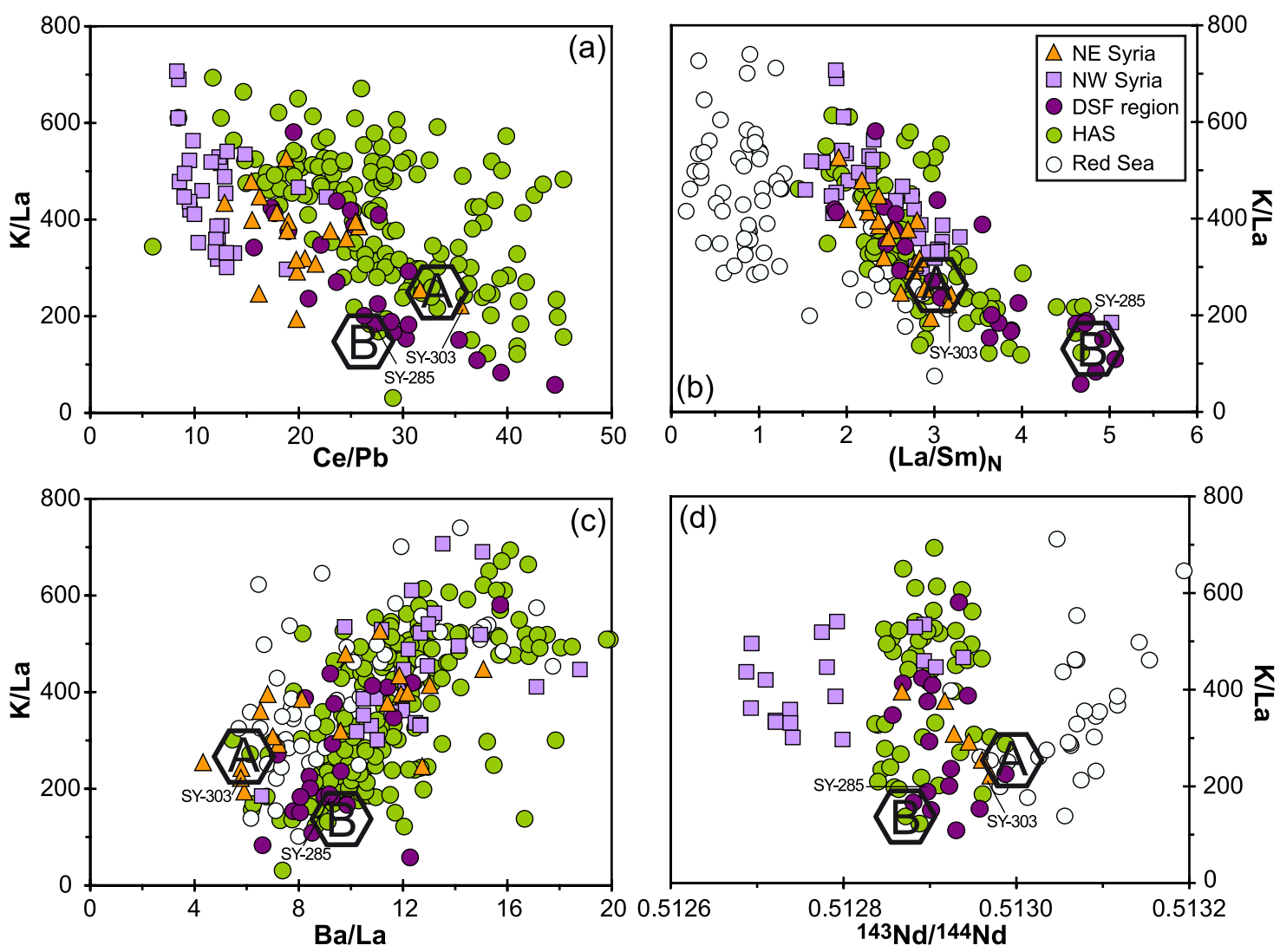

Figure 9. Variations of (a) $\mathrm{Ce} / \mathrm{Pb}$ versus $\mathrm{K} / \mathrm{La}$, (b) $(\mathrm{La} / \mathrm{Sm})_{\mathrm{N}}$ versus $\mathrm{K} / \mathrm{La}$, (c) $\mathrm{Ba} / \mathrm{La}$ versus $\mathrm{K} / \mathrm{La}$, and (d) ${ }^{143} \mathrm{Nd} /{ }^{144} \mathrm{Nd}$ versus $\mathrm{K} / \mathrm{La}$. Note that the displayed data also include crustally contaminated samples. Data sources are as in Figure 3, and chondrite-normalizing values are from McDonough and Sun [1995].

and $\mathrm{Ba}$ relative to other highly incompatible elements like $\mathrm{La}$ or $\mathrm{Nb}$ is often interpreted as being due to the reaction of the melt with a residual hydrous phase like amphibole or phlogopite with relatively high distribution coefficients for $\mathrm{K}, \mathrm{Rb}$, and Ba [e.g., Clague and Frey, 1982]. Alternatively, the relative depletion of these elements could be a mantle source signature similar to trace element characteristics observed in the so-called HIMUtype basalts [e.g., Sun and McDonough, 1989]. Lavas with $\mathrm{K} / \mathrm{La}>350$ most likely assimilated continental crustal material which is reflected in the negative trends between $\mathrm{K} / \mathrm{La},{ }^{143} \mathrm{Nd} /{ }^{144} \mathrm{Nd}$, and $\mathrm{Ce} / \mathrm{Pb}$ ratios (Figures $9 \mathrm{a}$ and $9 \mathrm{~d}$ ). Uncontaminated lavas show a negative correlation between $\mathrm{Ba} / \mathrm{La}$ and $\mathrm{K} / \mathrm{La}$ although a positive correlation would be expected if the $\mathrm{Ba}$ and $\mathrm{K}$ variation relative to $\mathrm{La}$ is due to residual amphibole or phlogopite in the mantle (Figure 9c). Consequently, we suggest that the variation of $\mathrm{Ba}, \mathrm{K}$, and $\mathrm{Rb}$ relative to $\mathrm{La}$ in the Syrian basalts reflects mixing of the two sublithospheric sources A and B rather than melting in the presence of a residual hydrous phase.

\subsection{Cause of Magma Generation Beneath Arabia}

[28] Extensive melting of mantle material at a normal potential temperature of $\sim 1300^{\circ} \mathrm{C}$ can only occur when the stretching factor of the lithosphere is between 2 and 5 [McKenzie and Bickle, 1988; White and McKenzie, 1989]. Camp and Roobol [1992] calculated a local lithospheric stretching factor beneath Saudi Arabia of only $~ 1.0$. An initial lithospheric thickness of $100-120 \mathrm{~km}$ underneath northwestern Arabia [Mooney et al., 1985] and a thinned lithospheric thickness of 75$80 \mathrm{~km}$ beneath Syria [Nasir and Safarjalani, 2000] and Saudi Arabia [McGuire and Bohannon, 1989] yields a stretching factor of 1.3 to 1.6 , too low to account for the abundant melt generation.

[29] Primary mantle-equilibrated melts have high $\mathrm{MgO}$ values whereas lower $\mathrm{MgO}$ contents of $\sim 9 \mathrm{wt}$ $\%$ in primitive magmas can be attributed to olivine fractionation which may be accompanied by minor removal of Cr-spinel. On the basis of calculated $\mathrm{Si}_{15}$ and $\mathrm{Fe}_{15}$ contents (see caption of Figure 10) we estimate the pressure and temperature condi- 


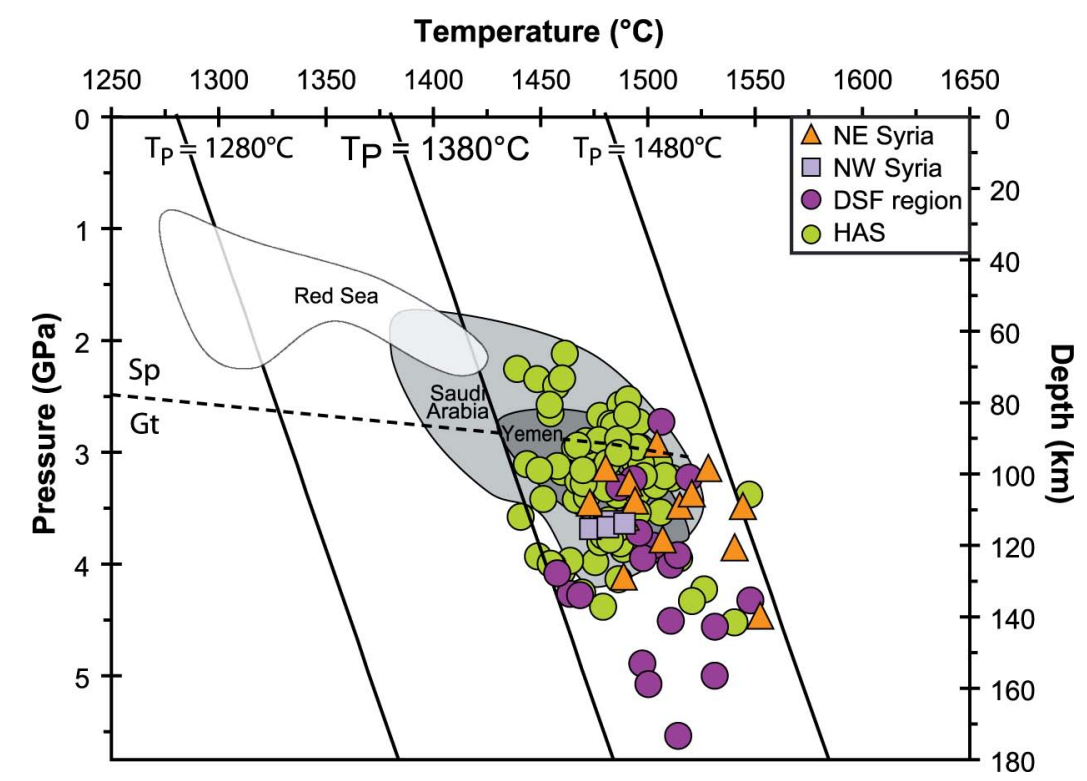

Figure 10. Pressure-temperature (P-T) diagram showing the conditions of magma generation. P-T estimates are based on calculated primary $\mathrm{Si}_{15}$ and $\mathrm{Fe}_{15}$ contents for the individual crustally uncontaminated Arabian and Red Sea lavas. Primary melting signatures were obtained by stepwise addition of equilibrium olivine to the fractionation corrected primitive magma compositions (with $\mathrm{MgO}=9 \mathrm{wt} \%$ ) until $\mathrm{MgO}$ values of $15 \mathrm{wt} \%$ (designated as subscript 15) are reached assuming that those basalts solely have fractionated olivine [Scarrow and Cox, 1995]. This MgO value appears suitable for representing the parental magma composition of Arabian lavas because it is slightly higher than the most MgO-rich volcanic rocks found in western Arabian and is comparable to the experimental determined range of primary melts with $\mathrm{MgO}$ contents ranging between $12 \%$ and $17 \%$ under anhydrous and hydrous conditions [e.g., Hirose and Kushiro, 1993]. Temperature estimates are based on the relation $\mathrm{T}\left({ }^{\circ} \mathrm{C}\right)=2000 *\left(\mathrm{MgO} / \mathrm{SiO}_{2} * \mathrm{MgO}\right)$ +969 with a mean square deviation of $40^{\circ} \mathrm{C}$ [Albarède, 1992], and pressure estimates are based on regression through HK 66 melting experiments [Hirose and Kushiro, 1993; Scarrow and Cox, 1995]. Pressure-to-depth conversion is made by the relationship depth $(\mathrm{km})=3.02 * \mathrm{P}(\mathrm{kbar})+5$ [Scarrow and Cox, 1995]. Additionally shown is a series of asthenospheric mantle adiabats for different potential mantle temperatures $\left(\mathrm{T}_{\mathrm{P}}=1280^{\circ} \mathrm{C}, 1380^{\circ} \mathrm{C}\right.$, and $\left.1480^{\circ} \mathrm{C}\right)$ [McKenzie and Bickle, 1988], and the dashed line indicates the spinel (Sp) to garnet (Gt) transition.

tions for the Arabian lavas using the method of Scarrow and Cox [1995]. Although the calculations based on several algebraic substitutions (fractionation correction, olivine addition, temperature calculation) the results appear reasonable and indicate magma formation at temperatures which were raised by $\sim 100-200^{\circ} \mathrm{C}$ compared to an average potential mantle temperature of about $1300^{\circ} \mathrm{C}$ [McKenzie and Bickle, 1988]. Such a temperature increase is in agreement with the 3 to $9 \%$ decrease of the $\mathrm{S}$ wave velocities below the Arabian Shield which have been estimated to be due to an excess temperature of 100 to $300^{\circ} \mathrm{C}$ [Park et al., 2007]. We suggest that increased mantle temperature prevailed beneath all of Arabia during the extensive melting events, most likely related to the influence of a mantle plume [e.g., White and McKenzie, 1989]. The young Syrian and Arabian lavas were generated at sublithospheric depths and melt formation has taken place at elevated mantle temperatures (Figure 10). Support for this theory is given by the elevated topography of these regions, by elevated geotherms calculated on the basis of mantle xenoliths [Al-Mishwat and Nasir, 2004; McGuire and Bohannon, 1989; Nasir and Safarjalani, 2000; Snyder et al., 1993] and by heat flow measurements [Gettings, 1981] as well as by seismic tomography, seismic anisotropy, $\mathrm{S}$ wave receiver function and shear wave splitting [Daradich et al., 2003; Hansen et al., 2006, 2007; Park et al., 2008].

\subsection{Origin of the Mantle Sources}

[30] As discussed above we suggest that the endmembers A and B in the Syrian lavas represent compositions of sublithospheric mantle sources. End-member A with low ${ }^{87} \mathrm{Sr} /{ }^{86} \mathrm{Sr}(\sim 0.7030)$, high ${ }^{143} \mathrm{Nd} /{ }^{144} \mathrm{Nd}(\sim 0.5130)$ and relatively unradiogenic $\mathrm{Pb}$ isotope ratios with, for example, a ${ }^{206} \mathrm{~Pb} /{ }^{204} \mathrm{~Pb}$ of $\sim 19.0$ is most clearly identified in some lavas from NE Syria and the DSF but also from the HAS group (Figure 5). This source 
appears to have relatively high $\mathrm{Ce} / \mathrm{Pb}$ and $\mathrm{Nb} / \mathrm{Th}$ (Figure 8). Mid-ocean ridge basalts (MORB) erupted in the Gulf of Aden and in the central and northern Red Sea probably represent the asthenosphere in the Arabian region [Altherr et al., 1988; Eissen et al., 1989; Haase et al., 2000; Schilling et al., 1992]. The similarity of end-member A in the Syrian lavas to incompatible element-enriched Red Sea basalts with relatively high $\mathrm{Sr}$ and $\mathrm{Pb}$ isotopes probably indicates that end-member A represents incompatible element-enriched portions within the asthenosphere (Figure 5). These enriched portions may be preferentially molten during the genesis of the alkali basaltic magmas and thus show no dilution by the more depleted matrix material of the asthenosphere surrounding them. End-member A is also observed in lavas from Yemen and Saudi Arabia and thus reflects the asthenospheric mantle component beneath Arabia (Figure 5).

[31] End-member B has low ${ }^{143} \mathrm{Nd} /{ }^{144} \mathrm{Nd}$ $(\sim 0.51287)$ and ${ }^{87} \mathrm{Sr} /{ }^{86} \mathrm{Sr}(0.7031-0.7033)$ but high $\mathrm{Pb}$ isotope compositions (e.g., ${ }^{206} \mathrm{~Pb} /{ }^{204} \mathrm{~Pb}$ $\sim 19.45$ ) resembling the source with radiogenic $\mathrm{Pb}$ isotopic composition affecting lavas from the Gulf of Aden, Saudi Arabia and Yemen (Figure 5) although the source of the latter have slightly higher $\mathrm{Pb}$ isotope ratios (e.g., ${ }^{206} \mathrm{~Pb} /{ }^{204} \mathrm{~Pb} \sim 19.6$ [Baker et al., 1996b; Schilling et al., 1992; Stewart and Rogers, 1996]). In fact, the isotope trends of all Arabian lavas converge on end-member B and thus, this source is abundant in the Arabian volcanic rocks as has been pointed out previously, e.g., by Bertrand et al. [2003]. It has been suggested that this component may represent northward flowing Afar plume material [Camp and Roobol, 1992; Schilling et al., 1992], fossil plume material residing in the subcontinental lithosphere [Bertrand et al., 2003; Stein and Hofmann, 1992], or material inserted into the asthenosphere by another mantle plume beneath the Arabian Plate [Camp and Roobol, 1992]. We discussed above that end-member B does most likely not reside in the subcontinental lithosphere, for example, because it is also observed in lavas from the Gulf of Aden and from the southern Red Sea [Rogers, 1993; Schilling et al., 1992], i.e., in lavas erupting through oceanic lithosphere. Rather, the high $\mathrm{Pb}$ isotope ratios in Syrian and other Arabian lavas are related to the relatively hot material beneath the Arabian Plate, i.e., to a broad anomalous mantle upwelling.

[32] The Afar deep mantle plume is well defined by seismic tomography [Debayle et al., 2001] and erupted large volumes of flood basalts over the past
30 Ma [e.g., Baker et al., 1996a; Hofmann et al., 1997; Ukstins et al., 2002]. Anomalies with slow seismic velocities suggest that Afar plume material has spread northward beneath the Arabian lithosphere and along the adjoining spreading axes of the Red Sea and Gulf of Aden rather than another plume being present beneath Arabia [Daradich et al., 2003; Debayle et al., 2001; Park et al., 2008]. There is broad consensus that one component of the Afar plume is defined by ${ }^{87} \mathrm{Sr} /{ }^{86} \mathrm{Sr} \sim 0.704$, ${ }^{143} \mathrm{Nd} /{ }^{144} \mathrm{Nd} \sim 0.51295$ and ${ }^{206} \mathrm{~Pb} /{ }^{204} \mathrm{~Pb} \sim 18.8$ [e.g., Schilling et al., 1992; Vidal et al., 1991] as well as high ${ }^{3} \mathrm{He} /{ }^{4} \mathrm{He}$ ratios [Marty et al., 1996; Pik et al., 1999]. Relatively undegassed material from the lower mantle agrees with seismic tomography showing a connection of the Afar plume into the lower mantle [e.g., Courtillot et al., 2003]. A similar isotopic plume composition but with slightly less radiogenic ${ }^{87} \mathrm{Sr} /{ }^{86} \mathrm{Sr}$ of $\sim 0.7036$ and ${ }^{143} \mathrm{Nd} /{ }^{144} \mathrm{Nd}$ of $\sim 0.51292$ and with ${ }^{206} \mathrm{~Pb} /{ }^{204} \mathrm{~Pb}$ between 18.4 and 19.0 has been proposed by Baker et al. [1996b, Figure 5a]. We conclude that this lower mantle Afar plume component cannot cause the observed isotopic variations in the Syrian lavas because it has too low $\mathrm{Pb}$ and too high $\mathrm{Sr}$ isotope ratios (Figure 5). However, source B occurs in the voluminous basalts in Yemen, the Gulf of Aden, Saudi Arabia, the Red Sea and Syria [Deniel et al., 1994; Schilling et al., 1992; Stewart and Rogers, 1996; Vidal et al., 1991] which are underlain by the seismic anomaly connected to the Afar plume [Daradich et al., 2003; Debayle et al., 2001]. Consequently, source B is most likely related to Afar plume mantle causing increased mantle temperatures and magma production beneath Arabia.

[33] Heterogeneous compositions of mantle plumes are known, for example, from Hawaii [e.g., Abouchami et al., 2005] and heterogeneities may form by entrainment during plume mantle upwelling [Griffiths and Campbell, 1990]. In that sense our interpretation agrees with the conclusion of Furman et al. [2006] who suggested that the high ${ }^{206} \mathrm{~Pb} /{ }^{204} \mathrm{~Pb}$ isotopic compositions of $>20.0$ found in lavas from the Turkana depression in the East African Rift System reflect the composition of entrained material that is related to a broad region of mantle upwelling, i.e., the African Superplume, of which the Afar mantle plume forms a part. Thus, there is strong evidence that our source B component with high $\mathrm{Pb}$ isotopic characteristics resides in the Afar plume. Consequently the observed isotopic variability of Syrian volcanism supports the model of northward directed mantle flow from the Afar region. 


\subsection{Northward Migration of Afar Mantle Plume Material}

[34] The Arabian swell, i.e., the Arabian part of the Afro-Arabian dome, is an area of elevated topography spanning from Yemen along western Arabia to Syria, may have formed by the inflow of material from the Afar area in the south [Camp and Roobol, 1992]. Volcanism started in Ethiopia and Yemen $\sim 31$ Ma ago [Ukstins et al., 2002] indicating the arrival of the Afar plume head which was accompanied by the onset of continental rifting [Hofmann et al., 1997]. The timing of onset of volcanism of the entire Afro-Arabian region reveals a south to north progression for the initiation of volcansim [Ershov and Nikishin, 2004, Figure 7]. The northward migration of volcanism with time may be related to the flattening of the Afar plume head and northward channeling of plume flow underneath Arabia [Camp and Roobol, 1992; Ebinger and Sleep, 1998]. Presently, such a flow of hot material to the north is supported by seismic tomography and shear wave splitting studies [Daradich et al., 2003; Debayle et al., 2001; Hansen et al., 2006; Park et al., 2008]. This plume flow may have also caused the older volcanic activity in NW Syria, but here much smaller volumes of magmas imply only weak inflow of hot mantle. In contrast, the voluminous volcanism especially between 4.5 and $3 \mathrm{Ma}$ forming more than $700 \mathrm{~m}$ of lavas in the HAS volcanic field requires elevated mantle temperatures [Krienitz et al., 2007]. Contemporaneous abundant volcanism in NE Syria and along the Dead Sea Fault (Figure 6 ) indicates that a strong pulse of hot mantle affected the whole region.

[35] Although isotope data of Syrian lavas provide strong evidence for the involvement of an Afar mantle plume component the far-scale influence of the plume material over a distance of more than $2500 \mathrm{~km}$ exceeds the predicted dimensions ( $\sim 2000$ $\mathrm{km}$ in diameter) of flattened plume heads [Griffiths and Campbell, 1990] and also the extent of the Afar plume that, on the basis of $\mathrm{Sr}, \mathrm{Nd}, \mathrm{Pb}$, and $\mathrm{He}$ isotopes in lavas, has a radius of only $1000 \mathrm{~km}$ [Marty et al., 1996; Schilling et al., 1992, Figure 1]. Such a far-ranging influence of the Afar plume material on the genesis of the Syrian lavas requires lateral material flow. Lateral plume flow is common, for example, beneath the oceanic lithosphere where plume mantle is laterally transported up to $1000 \mathrm{~km}$ from a rising plume into an adjacent midoceanic spreading axis [e.g., Ito et al., 2003]. Combining only the most reliable Ar-Ar ages of lavas in northern Syria $(\sim 19 \mathrm{Ma})$ and Yemen $(\sim 31 \mathrm{Ma})$ with the distance of about $2600 \mathrm{~km}$ between the two locations results in an average lateral flow velocity of the plume material of about $22 \mathrm{~cm} / \mathrm{a}$ (Figure 7). This mantle flow velocity of the Afar plume material is similar to the lower end of estimated velocities of Iceland plume migration along the Reykjanes Ridge spreading axis (16 to > $100 \mathrm{~cm} / \mathrm{a}$ [Wright and Miller, 1996]).

[36] Generally, the spreading of the plume material is controlled by the thickness of the lithosphere where plume heads spread preferentially in the direction of the thinnest lithosphere. The focused flow to the north may have been caused by the thick Early Proterozoic to Archaean lithosphere of the African, Tanzania and Arabian cratons lying to the west, south and east of the Afar region [Ebinger and Sleep, 1998], whereas the Precambrian basement of western Arabia situated in the north of the Afar area is of relatively dense and thin lithosphere composed of accreted oceanic terranes [e.g., Stoeser and Frost, 2006]. Supporting evidence for relatively recent northward flow of Afar plume material comes from the asymmetric uplift of the Dead Sea Transform [Sobolev et al., 2005] and is suggested by Hopp et al. [2004] on the basis of noble gas isotope systematic in Arabian mantle xenoliths. We conclude that the existing geochemical, geochronological and seismic data suggest a very large area of influence of the Afar plume beneath the Arabian Plate.

\section{Conclusions}

[37] The spatiotemporal distribution of Syrians volcanism and the similarities of $\mathrm{Sr}, \mathrm{Nd}$, and $\mathrm{Pb}$ isotope compositions of Syrian lavas to other Arabian basalts suggest the inflow of hot material from the Afar plume in the south. The generation of several basalt eruptions can be explained by local tectonic processes above anomalously hot mantle and three main volcanic phases can be distinguished since the early Miocene. The oldest volcanism (21 to $16 \mathrm{Ma}$ ) occurred in southern Syria and in the Aleppo region and coincides with the first period of movement along the Dead Sea Fault system. The second volcanic phase (between 12 and $9 \mathrm{Ma}$ ) mainly affected the Aleppo region in northwest Syria and could be induced by slab break-off at the Bitlis suture zone. The youngest volcanic phase started about $6 \mathrm{Ma}$ ago in Syria and most voluminously with the eruption of most of the HAS plateau. This phase is synchronous with the 
second phase of movement along the Dead Sea Fault system that may have triggered this renewal of volcanism. However, the volume of magmas in the HAS as well as the abundance of volcanism younger than about $5 \mathrm{Ma}$ in northern Syria is probably caused by the northward migration of the hot mantle plume material underlying the region at present.

[38] Low $\mathrm{Ce} / \mathrm{Pb}$ and $\mathrm{Nb} / \mathrm{Th}$ ratios in lavas reveal that crustal contamination contributed to their magma genesis and mixing calculations on the basis of their isotopic composition indicate that lavas have assimilated up to $30 \%$ of continental crustal material during their ascent. Fractionationcorrected major element compositions and rare earth element ratios of crustally uncontaminated lavas indicate a pressure control, i.e., lithospheric thickness, on the melting regime in western Arabia and calculated primary compositions of crustally uncontaminated lavas suggest that the lavas were generated at elevated $\left(100-200^{\circ} \mathrm{C}\right)$ mantle temperatures as being characteristic for their generation in a plume mantle region. The $\mathrm{Sr}, \mathrm{Nd}$, and $\mathrm{Pb}$ isotope compositions of crustally uncontaminated lavas indicate that asthenospheric and mantle plume source components contribute to their formation, whereas a lithospheric origin can be excluded. The isotopic compositions of the mantle plume source resemble those from southern Arabian locations clearly related to Afar plume volcanism.

[39] The northward directed age progression of the onset of volcanic activity, the distribution of magma sources, and the increasingly deeper partial melting toward the north reveal the spreading of Afar plume material beneath the Arabian lithosphere. The plume material flowed northward at a rate of about $22 \mathrm{~cm} / \mathrm{a}$ and over a distance of at least $2600 \mathrm{~km}$. The presence of this relatively hot material enabled significant partial melting even beneath regions with minor lithospheric thinning.

\section{Acknowledgments}

[40] The authors thank H. Baier, H. Blaschek, D. GarbeSchönberg, K. Kißling, and A. Weinkauf for their professional assistance during the analytical work. Zaghier Ali is acknowledged for his help during field work. Thoughtful and very constructive reviews by Tanya Furman and Anthony Koppers helped to improve the quality of the manuscript, and we thank John Tarduno for editorial handling. This study was funded by the Deutsche Forschungsgemeinschaft (DFG, grant HA 2568/ $5)$, which is gratefully acknowledged.

\section{References}

Abouchami, W., A. W. Hofmann, S. Galer, F. A. Frey, J. Eisele, and M. Feigenson (2005), Lead isotopes reveal bilateral asymmetry and vertical continuity in the Hawaiian mantle plume, Nature, 434, 851-856, doi:10.1038/ nature 03402 .

Albarède, F. (1992), How deep do common basaltic magmas form and differentiate?, J. Geophys. Res., 97, 10,99711,009, doi:10.1029/91JB02927.

Al-Mishwat, A. T., and S. J. Nasir (2004), Composition of the lower crust of the Arabian Plate: A xenolith perspective, Lithos, 72, 45-72, doi:10.1016/j.lithos.2003.08.003.

Almond, D. C. (1986), Geological evolution of the AfroArabian Dome, Tectonophysics, 131, 301-332, doi:10.1016/0040-1951(86)90180-0.

Altherr, R., F. Henjes-Kunst, H. Puchelt, and A. Baumann (1988), Volcanic activity in the Red Sea axial trough-evidence for a large mantle diapir?, Tectonophysics, 150, 121-133, doi:10.1016/0040-1951(88)90298-3.

Altherr, R., F. Henjes-Kunst, and A. Baumann (1990), Asthenosphere versus lithosphere as possible sources for basaltic magmas erupted during formation of the Red Sea: Constraints from $\mathrm{Sr}, \mathrm{Pb}$ and $\mathrm{Nd}$ isotopes, Earth Planet. Sci. Lett., 96, 269-286, doi:10.1016/0012-821X(90)90007-K.

Baker, J. A., L. W. Snee, and M. A. Menzies (1996a), A brief Oligocene period of flood volcanism in Yemen; implications for the duration and rate of continental flood volcanism at the Afro-Arabian triple junction, Earth Planet. Sci. Lett., $138(1-$ 4), 39-55, doi:10.1016/0012-821X(95)00229-6.

Baker, J. A., M. F. Thirlwall, and M. A. Menzies (1996b), Sr$\mathrm{Nd}-\mathrm{Pb}$ isotopic and trace element evidence for crustal contamination of plume-derived flood basalts; Oligocene flood volcanism in western Yemen, Geochim. Cosmochim. Acta, 60, 2559-2581, doi:10.1016/0016-7037(96)00105-6.

Baker, J. A., M. A. Menzies, M. F. Thirlwall, and C. G. Macpherson (1997), Petrogenesis of Quaternary intraplate volcanism, Sana'a, Yemen: Implications for plume-lithosphere interaction and polybaric melt hybridization, J. Petrol., 38, 1359-1390, doi:10.1093/petrology/38.10.1359.

Baker, J., G. Chazot, M. Menzies, and M. Thirlwall (1998), Metasomatism of the shallow mantle beneath Yemen by the Afar Plume-Implications for mantle plumes, flood volcanism, and intraplate volcanism, Geology, 26, 431-434, doi:10.1130/0091-7613(1998)026<0431:MOTSMB >2.3. $\mathrm{CO} ; 2$.

Baker, M. B., and E. M. Stolper (1994), Determining the composition of high-pressure mantle melts using diamond aggregates, Geochim. Cosmochim. Acta, 58, 2811-2827, doi:10.1016/0016-7037(94)90116-3.

Barberi, F., G. Capaldi, P. Gasperini, G. Marinelli, R. Santacroce, R. Scandone, M. Treuil, and J. Varet (1980), Recent basaltic volcanism of Jordan and its implications on the geodynamic history of the Dead Sea shear zone, in Geodynamic Evolution of the Afro-Arabian Rift System, edited by A. Carrelli, pp. 667-683, Acad. Naz. dei Lincei, Rome.

Bartov, Y., G. Steinitz, M. Eyal, and Y. Eyal (1980), Sinistral movement along the Gulf of Aqaba-Its age and relation to the opening of the Red Sea, Nature, 285, 220-222, doi:10.1038/285220a0.

Baubron, J. C., and R. C. Maury (1980), Age and petrology of the Jabal Abyad volcanic chain, Khaybar plateau, Saudi Arabia, in Geodynamic Evolution of the Afro-Arabian Rift System, edited by A. Carrelli, pp. 655-666, Acad. Naz. dei Lincei, Rome. 
Bertrand, H., G. Chazot, J. Blichert-Toft, and S. Thoral (2003), Implications of widespread high- $\mu$ volcanism on the Arabian Plate for Afar mantle plume and lithosphere composition, Chem. Geol., 198, 47-61, doi:10.1016/S00092541(02)00418-7.

Blusztajn, J., S. R. Hart, N. Shimizu, and A. V. McGuire (1995), Trace-element and isotopic characteristics of spinel peridotite xenoliths from Saudi Arabia, Chem. Geol., 123, 53-65, doi:10.1016/0009-2541(95)00044-M.

Bohannon, R. G., C. W. Naeser, D. L. Schmidt, and R. A. Zimmermann (1989), The timing of uplift, volcanism, and rifting peripheral to the Red Sea: A case for passive rifting?, J. Geophys. Res., 94, 1683-1701, doi:10.1029/ JB094iB02p01683.

Brew, G., M. Barazangi, A. K. Al-Maleh, and T. Sawaf (2001), Tectonic and geologic evolution of Syria, Geoarabia, 6, $573-616$

Butler, R. W. H., S. Spencer, and H. M. Griffiths (1997), Transcurrent fault activity on the Dead Sea transform in Lebanon and its implications for plate tectonics and seismic hazard, J. Geol. Soc., 154(5), 757-760, doi:10.1144/ gsjgs.154.5.0757.

Camp, V. E., and M. J. Roobol (1989), The Arabian continental alkali basalt province: Part I. Evolution of Harrat Rahat, Kingdom of Saudi Arabia, Geol. Soc. Am. Bull., 101, 71-95, doi:10.1130/0016-7606(1989)101<0071:TACABP $>2.3$. $\mathrm{CO} ; 2$

Camp, V. E., and M. J. Roobol (1992), Upwelling asthenosphere beneath western Arabia and its regional implications, J. Geophys. Res., 97, 15,255-15,271, doi:10.1029/ 92JB00943.

Camp, V. E., M. J. Roobol, and P. R. Hooper (1991), The Arabian continental alkali basalt province: Part II. Evolution of Harrats Khaybar, Ithnayn, and Kura, Kingdom of Saudi Arabia, Geol. Soc. Am. Bull., 103, 363-391, doi:10.1130/ 0016-7606(1991)103<0363:TACABP $>2.3 . C O ; 2$.

Clague, D. A., and F. A. Frey (1982), Petrology and trace element geochemistry of the Honolulu Volcanics, Oahu: Implications for the oceanic mantle below Hawaii, J. Petrol., 23(3), 447-504

Courtillot, V., A. Davaille, J. Besse, and J. Stock (2003), Three distinct types of hotspots in the Earth's mantle, Earth Planet. Sci. Lett., 205, 295-308, doi:10.1016/S0012821X(02)01048-8

Daradich, A., J. X. Mitrovica, R. N. Pysklywec, S. D. Willett, and A. M. Forte (2003), Mantle flow, dynamic topography, and rift-flank uplift of Arabia, Geology, 31, 901-904, doi:10.1130/G19661.1.

Debayle, E., J. J. Leveque, and M. Cara (2001), Seismic evidence for a deeply rooted low-velocity anomaly in the upper mantle beneath the northeastern Afro/Arabian continent, Earth Planet. Sci. Lett., 193, 423-436, doi:10.1016/ S0012-821X(01)00509-X.

Demir, T., R. Westaway, D. Bridgland, M. Pringle, S. Yurtmen, A. Beck, and G. Rowbotham (2007), Ar-Ar dating of late Cenozoic basaltic volcanism in northern Syria: Implications for the history of incision by the River Euphrates and uplift of the northern Arabian Platform, Tectonics, 26, TC3012, doi:10.1029/2006TC001959.

Deniel, C., P. Vidal, C. Coulon, P.-J. Vellutini, and P. Piguet (1994), Temporal evolution of mantle sources during continental rifting: The volcanism of Djibouti (Afar), J. Geophys. Res., 99, 2853-2869, doi:10.1029/93JB02576.

du Bray, E. A., D. B. Stoeser, and E. H. McKee (1991), Age and petrology of the Tertiary As Sarat volcanic field, south- western Saudi Arabia, Tectonophysics, 198, 155-180, doi:10.1016/0040-1951(91)90149-M.

Duffield, W. A., and G. B. Dalrymple (1990), The Taylor Creek Rhyolite of New Mexico: A rapidly emplaced field of lava domes and flows, Bull. Volcanol., 52, 475-487, doi:10.1007/BF00268927.

Duncan, R. A., and M. A. Richards (1991), Hotspots, mantle plumes, flood basalts, and true polar wander, Rev. Geophys., 29, 31-50, doi:10.1029/90RG02372.

Ebinger, C. J., and N. H. Sleep (1998), Cenozoic magmatism throughout east Africa resulting from impact of a single plume, Nature, 395, 788-791, doi:10.1038/27417.

Eissen, J. P., T. Juteau, J. L. Joron, B. Dupré, E. Humler, and A. Al'Mukhamedov (1989), Petrology and geochemistry of basalts from the Red Sea axial rift at 18 degrees north, J. Petrol., 30, 791-839.

Ershov, A. V., and A. M. Nikishin (2004), Recent geodynamics of the Caucasus-Arabia-East Africa Region, Geotectonics, Engl. Transl., 38(2), 123-136.

Faccenna, C., O. Bellier, J. Martinod, C. Piromallo, and V. Regard (2006), Slab detachment beneath eastern Anatolia: A possible cause for the formation of the North Anatolian fault, Earth Planet. Sci. Lett., 242, 85-97, doi:10.1016/ j.epsl.2005.11.046.

Fram, M. S., and C. E. Lesher (1993), Geochemical constraints on mantle melting during creation of the North Atlantic basin, Nature, 363, 712-715, doi:10.1038/363712a0.

Furman, T., K. M. Kaleta, J. G. Bryce, and B. B. Hanan (2006), Tertiary mafic lavas of Turkana, Kenya: Constraints on East African plume structure and the occurrence of high- $\mu$ volcanism in Africa, J. Petrol., 47, 1221-1244, doi:10.1093/ petrology/eg1009.

Gallagher, K., and C. J. Hawkesworth (1992), Dehydration melting and the generation of continental flood basalts, Nature, 358, 57-59, doi:10.1038/358057a0.

Garrido, C. J., J.-L. Bodinier, and O. Alard (2000), Incompatible trace element partitioning and residence in anhydrous spinel peridotites and websterites from the Ronda orogenic peridotite, Earth Planet. Sci. Lett., 181, 341-358, doi:10.1016/S0012-821X(00)00201-6.

Gettings, M. E. (1981), A heat flow profile across the Arabian Shield and Red Sea, Eos Trans. AGU, 62, 407.

Giannérini, G., R. Campredon, G. Féraud, and Z. B. Abou (1988), Déformations intraplaques et volcanisme associé; exemple de la bordure NW de la plaque Arabique au Cénozoïque (Intraplate deformation and associated volcanism; example of the northwestern edge of the Arabian Plate during the Cenozoic), Bull. Soc. Geol. Fr., 4(6), 937-947.

Girdler, R. W. (1990), The Dead Sea transform fault system, Tectonophysics, 180(1), 1-13, doi:10.1016/00401951(90)90367-H.

Gomez, F., M. Khawlie, C. Tabet, A. N. Darkal, K. Khair, and M. Barazangi (2006), Late Cenozoic uplift along the northern Dead Sea transform in Lebanon and Syria, Earth Planet. Sci. Lett., 241, 913-931, doi:10.1016/j.epsl.2005.10.029.

Griffiths, R. W., and I. H. Campbell (1990), Stirring and structure in mantle starting plumes, Earth Planet. Sci. Lett., 99, 66-78, doi:10.1016/0012-821X(90)90071-5.

Guba, I., and H. Mustafa (1988), Structural control of young basaltic fissure eruptions in the plateau basalt area of the Arabian Plate, northeastern Jordan, J. Volcanol. Geotherm. Res., 35, 319-334, doi:10.1016/0377-0273(88)90026-1.

Haase, K. M., R. Muehe, and P. Stoffers (2000), Magmatism during extension of the lithosphere; geochemical constraints from lavas of the Shaban Deep, northern Red 
Sea, Chem. Geol., 166(3-4), 225-239, doi:10.1016/S00092541(99)00221-1.

Hansen, S., S. Schwartz, A. Al-Amri, and A. Rodgers (2006), Combined plate motion and density-driven flow in the asthenosphere beneath Saudi Arabia: Evidence from shear-wave splitting and seismic anisotropy, Geology, 34, 869-872, doi:10.1130/G22713.1.

Hansen, S. E., A. J. Rodgers, S. Y. Schwartz, and A. M. S. Al-Amri (2007), Imaging ruptured lithosphere beneath the Red Sea and Arabian Peninsula, Earth Planet. Sci. Lett., 259, 256-265, doi:10.1016/j.eps1.2007.04.035.

Harlow, G. E., and R. Davies (2004), Status report on stability of K-rich phases at mantle conditions, Lithos, 77, 647-653, doi:10.1016/j.lithos.2004.04.010.

Hart, S. R., E. H. Hauri, L. A. Oschmann, and J. A. Whitehead (1992), Mantle plumes and entrainment: Isotopic evidence, Science, 256, 517-520, doi:10.1126/science.256.5056.517.

Hauri, E. H., J. A. Whitehead, and S. R. Hart (1994), Fluid dynamics and geochemical aspects of entrainment in mantle plumes, J. Geophys. Res., 99(B12), 24,275-24,300, doi:10.1029/94JB01257.

Hegner, E., and J. S. Pallister (1989), Pb, Sr, and Nd isotopic characteristics of Tertiary Red Sea Rift volcanics from the central Saudi Arabian coastal plain, J. Geophys. Res., 94, 7749-7755, doi:10.1029/JB094iB06p07749.

Hempton, M. R. (1987), Constraints on Arabian Plate motion and extensional history of the Red Sea, Tectonics, 6(6), 687705, doi:10.1029/TC006i006p00687.

Henjes-Kunst, F., R. Altherr, and A. Baumann (1990), Evolution and composition of the lithospheric mantle underneath the western Arabian Peninsula: Constraints from Sr-Nd isotope systematics of mantle xenoliths, Contrib. Mineral. Petrol., 105, 460-472, doi:10.1007/BF00286833.

Hirose, K., and I. Kushiro (1993), Partial melting of dry peridotites at high pressures: Determination of compositions of melts segregated from peridotite using aggregates of diamond, Earth Planet. Sci. Lett., 114(4), 477-489, doi:10.1016/0012-821X(93)90077-M.

Hofmann, A. W. (2003), Sampling mantle heterogeneity through oceanic basalts: Isotopes and trace elements, in Treatise on Geochemistry, edited by $\mathrm{H}$. Holland and K. K. Turekian, pp. 61-101, Elsevier, Oxford, U. K.

Hofmann, A. W., K. P. Jochum, M. Seufert, and W. M. White (1986), $\mathrm{Nb}$ and $\mathrm{Pb}$ in oceanic basalts; new constraints on mantle evolution, Earth Planet. Sci. Lett., 79, 33-45, doi:10.1016/0012-821X(86)90038-5.

Hofmann, C., V. Courtillot, G. Feraud, P. Rouchett, G. Yirgu, E. Ketefo, and R. Pik (1997), Timing of the Ethiopian flood basalt event and implications for plume birth and global change, Nature, 389, 838-841, doi:10.1038/39853.

Hopp, J., M. Trieloff, and R. Altherr (2004), Neon isotopes in mantle rocks from the Red Sea region reveal large-scale plume-lithosphere interaction, Earth Planet. Sci. Lett., 219, 61-76, doi:10.1016/S0012-821X(03)00691-5.

Ilani, S., Y. Harlavan, K. Tarawneh, I. Rabba, R. Weinberger, K. Ibrahim, S. Peltz, and G. Steinitz (2001), New K-Ar ages of basalts from the Harrat Ash Shaam volcanic field in Jordan: Implications for the span and duration of the uppermantle upwelling beneath the western Arabian plate, Geology, 29, 171-174, doi:10.1130/0091-7613(2001)029<0171: NKAAOB $>2.0 . \mathrm{CO} ; 2$.

Ito, G., J. Lin, and D. Graham (2003), Observational and theoretical studies of the dynamics of mantle plume-mid-ocean ridge interaction, Rev. Geophys., 41(4), 1017, doi:10.1029/ 2002RG000117.
Jaques, A. L., and D. H. Green (1980), Anhydrous melting of peridotite at $0-15 \mathrm{~kb}$ pressure and the genesis of tholeiitic basalts, Contrib. Mineral. Petrol., 73, 287-310, doi:10.1007/BF00381447.

Jarrar, G., R. J. Stern, G. Saffarini, and H. Al-Zubi (2003), Late- and post-orogenic Neoproterozoic intrusions of Jordan: Implications for crustal growth in the northernmost segment of the East African Orogen, Precambrian Res., 123, 295 319, doi:10.1016/S0301-9268(03)00073-1.

Johnson, K. T. M. (1998), Experimental determination of partition coefficients for rare earth and high-field-strength elements between clinopyroxene, garnet, and basaltic melt at high pressure, Contrib. Mineral. Petrol., 133, 60-68, doi:10.1007/s004100050437.

Kelemen, P. B., N. Shimizu, and T. Dunn (1993), Relative depletion of niobium in some arc magmas and the continental crust: Partitioning of $\mathrm{K}, \mathrm{Nb}, \mathrm{La}$ and Ce during melt/rock reaction in the upper mantle, Earth Planet. Sci. Lett., 120, 111-133, doi:10.1016/0012-821X(93)90234-Z.

Keskin, M. (2003), Magma generation by slab steepening and breakoff beneath a subduction-accretion complex: An alternative model for collision-related volcanism in Eastern Anatolia, Turkey, Geophys. Res. Lett., 30(24), 8046, doi:10.1029/2003GL018019.

Klein, E. M., and C. H. Langmuir (1987), Global correlations of ocean ridge basalt chemistry with axial depth and crustal thickness, J. Geophys. Res., 92, 8089-8115, doi:10.1029/ JB092iB08p08089.

Krienitz, M.-S., K. M. Haase, K. Mezger, V. Eckardt, and M. A. Shaikh-Mashail (2006), Magma genesis and crustal contamination of continental intraplate lavas in northwestern Syria, Contrib. Mineral. Petrol., 151(6), 698-716, doi:10.1007/s00410-006-0088-1.

Krienitz, M.-S., K. M. Haase, K. Mezger, and M. A. ShaikhMashail (2007), Magma genesis and mantle dynamics at the Harrat Ash Shamah Volcanic Field (southern Syria), J. Petrol., 48, 1513-1542, doi:10.1093/petrology/egm028.

Langmuir, C. H., E. M. Klein, and T. Plank (1992), Petrological systematics of mid-ocean ridge basalts: Constraints on melt generation beneath ocean ridges, in Mantle Flow and Melt Generation at Mid-Ocean Ridges, Geophys. Monogr. Ser, vol. 71, edited by J. P. Morgan, D. K. Blackmann, and J. M. Sinton, pp. 183-280, AGU, Washington, D. C.

Lustrino, M., and E. V. Sharkov (2006), Neogene volcanic activity of western Syria and its relationship with Arabian plate kinematics, J. Geodyn., 42, 115-139, doi:10.1016/ j.jog.2006.06.003.

Manetti, P., G. Capaldi, S. Chiesa, L. Civetta, S. Conticelli, M. Gasparon, V. L. La, and G. Orsi (1991), Magmatism of the eastern Red Sea margin in the northern part of Yemen from Oligocene to present, Tectonophysics, 198, 181-202, doi:10.1016/0040-1951(91)90150-Q.

Marty, B., R. Pik, and Y. Gezahegn (1996), Helium isotopic variations in Ethiopian plume lavas: Nature of magmatic sources and limit on lower mantle contribution, Earth Planet. Sci. Lett., 144, 223-237, doi:10.1016/0012821X(96)00158-6.

McDonough, W. F., and S.-S. Sun (1995), The composition of the Earth, Chem. Geol., 120, 223-253, doi:10.1016/00092541(94)00140-4.

McGuire, A. V., and R. G. Bohannon (1989), Timing of mantle upwelling: Evidence for a passive origin for the Red Sea Rift, J. Geophys. Res., 94, 1677-1682, doi:10.1029/ JB094iB02p01677. 
McKenzie, D., and M. J. Bickle (1988), The volume and composition of melt generated by extension of the lithosphere, J. Petrol., 29(3), 625-679.

Mohsen, A., R. Kind, S. V. Sobolev, M. Weber, and the DESERT Group (2006), Thickness of the lithosphere east of the Dead Sea Transform, Geophys. J. Int., 167, 845-852, doi:10.1111/j.1365-246X.2006.03185.x.

Mooney, W. D., M. E. Gettings, H. R. Blank, and J. H. Healy (1985), Saudi Arabian seismic-refraction profile: A traveltime interpretation of crustal and upper mantle structure, Tectonophysics, 111, 173-246, doi:10.1016/00401951(85)90287-2.

Mouty, M., M. Delaloye, D. Fontignie, O. Piskin, and J. J. Wagner (1992), The volcanic activity in Syria and Lebanon between Jurassic and Actual, Schweiz. Mineral. Petrogr. Mitt., 72(1), 91-105

Nasir, S., and A. Safarjalani (2000), Lithospheric petrology beneath the northern part of the Arabian Plate in Syria: Evidence from xenoliths in alkali basalts, J. Afr. Earth Sci., 30, 149-168, doi:10.1016/S0899-5362(00)00013-0.

Pallister, J. S. (1987), Magmatic history of Red Sea rifting: Perspective from the central Saudi Arabian coastal plain, Geol. Soc. Am. Bull., 98(4), 400-417, doi:10.1130/00167606(1987)98<400:MHORSR>2.0.CO;2.

Park, Y., A. A. Nyblade, A. J. Rodgers, and A. Al-Amri (2007), Upper mantle structure beneath the Arabian Peninsula and northern Red Sea from teleseismic body wave tomography: Implications for the origin of Cenozoic uplift and volcanism in the Arabian Shield, Geochem. Geophys. Geosyst., 8, Q06021, doi:10.1029/2006GC001566.

Park, Y., A. A. Nyblade, A. Rodgers, and A. Al-Amri (2008), $\mathrm{S}$ wave velocity structure of the Arabian Shield upper mantle from Rayleigh wave tomography, Geochem. Geophys. Geosyst., 9, Q07020, doi:10.1029/2007GC001895.

Pearce, J. A., J. F. Bender, S. E. De Long, W. S. F. Kidd, P. J. Low, Y. Güner, F. Saroglu, Y. Yilmaz, S. Moorbath, and J. G. Mitchell (1990), Genesis of collision volcanism in Eastern Anatolia, Turkey, J. Volcanol. Geotherm. Res., 44, 189-229, doi:10.1016/0377-0273(90)90018-B.

Pik, R., C. Deniel, C. Coulon, G. Yirgu, C. Hofmann, and D. Ayalew (1998), The northwestern Ethiopian Plateau flood basalts: Classification and spatial distribution of magma types, J. Volcanol. Geotherm. Res., 81, 91-111, doi:10.1016/S0377-0273(97)00073-5.

Pik, R., C. Deniel, C. Coulon, G. Yirgu, and B. Marty (1999), Isotopic and trace element signatures of Ethiopian flood basalts: Evidence for plume-lithosphere interactions, Geochim. Cosmochim. Acta, 63, 2263-2279, doi:10.1016/S00167037(99)00141-6.

Ponikarov, V. P., L. Protasevich, A. Maximov, and G. Tkachev (1963), Geological map of Syria, scale 1:200,000, V.O. Technoexport, Moscow.

Rogers, N. W. (1993), The isotope and trace element geochemistry of basalts from the volcanic islands of the southern Red Sea, J. Geol. Soc., 76, 455-467.

Rudnick, R. L., and D. M. Fountain (1995), Nature and composition of the continental crust: A lower crustal perspective, Rev. Geophys., 33, 267-309, doi:10.1029/95RG01302.

Scarrow, J. H., and K. G. Cox (1995), Basalts generated by decompressive adiabatic melting of a mantle plume; a case study from the Isle of Skye, NW Scotland, J. Petrol., 36(1), $3-22$.

Scarrow, J. H., J. M. Curran, and A. C. Kerr (2000), Major element records of variable plume involvement in the North Atlantic Province tertiary flood basalts, J. Petrol., 41(7), 1155-1176, doi:10.1093/petrology/41.7.1155.
Schattner, U., Z. Ben-Avraham, Z. Reshef, G. Bar-Am, and M. Lazar (2006), Oligocene-Miocene formation of the Haifa basin: Qishon-Sirhan rifting coeval with the Red Sea-Suez rift system, Tectonophysics, 419, 1-12, doi:10.1016/j.tecto.2006.03.009.

Schilling, J. G. (1973), Afar mantle plume: Rare earth evidence, Nature, 242, 565-571, doi:10.1038/242565a0.

Schilling, J. G., R. H. Kingsley, B. B. Hanan, and B. L. McCully (1992), Nd-Sr-Pb isotopic variations along the Gulf of Aden: Evidence for Afar mantle plume-continental lithosphere interaction, J. Geophys. Res., 97, 10,927-10,966, doi:10.1029/92JB00415.

Sebai, A., V. Zumbo, G. Feraud, H. Bertrand, A. G. Hussain, G. Giannerini, and R. Campredon (1991), ${ }^{40} \mathrm{Ar} /{ }^{39} \mathrm{Ar}$ dating of alkaline and tholeiitic magmatism of Saudi Arabia related to the early Red Sea rifting, Earth Planet. Sci. Lett., 104, 473-487, doi:10.1016/0012-821X(91)90223-5.

Sen, P. A., A. Temel, and A. Gourgaud (2004), Petrogenetic modelling of Quaternary post-collisional volcansim: A case study of central and eastern Anatolia, Geol. Mag., 141, 8198, doi:10.1017/S0016756803008550.

Sharkov, Y. V., I. V. Chernyshev, Y. V. Devyatkin, A. Y. Dodonov, V. V. Ivanenko, M. I. Karpenko, Y. G. Leonov, V. M. Novikov, S. Hanna, and K. Khatib (1994), Geokhronologiya pozdnekaynozoyskikh bazal'tov Zapadnoy Sirii (Geochronology of late Cenozoic basalts in western Syria), Petrologiya, 2, 385-394.

Sharkov, Y. V., I. V. Chernyshev, E. V. Devyatkin, A. E. Dodonov, V. V. Ivanenko, M. I. Karpenko, V. A. Lebedev, V. M. Novikov, S. Hanna, and K. Khatib (1998), New data on the geochronology of upper Cenozoic plateau basalts from the northeastern periphery of the Red Sea Rift area (northern Syria), Dokl. Acad. Sci. USSR, Earth. Sci. Sect., Engl. Transl., 358, 19-22.

Shaw, J. E., J. A. Baker, M. A. Menzies, M. F. Thirlwall, and K. M. Ibrahim (2003), Petrogenesis of the largest intraplate volcanic field on the Arabian Plate (Jordan): A mixed lithosphere-asthenosphere source activated by lithospheric extension, J. Petrol., 44, 1657-1679, doi:10.1093/petrology/ egg052.

Sims, K. W. W., and D. J. DePaolo (1997), Inferences about mantle magma sources from incompatible element concentration ratios in oceanic basalts, Geochim. Cosmochim. Acta, 61, 765-784, doi:10.1016/S0016-7037(96)00372-9.

Snyder, G. A., L. A. Taylor, E. A. Jerde, Y. Sharkov, Y. Lazky, and S. Hanna (1993), Petrogenesis of garnet pyroxenite and spinel peridotite xenoliths of the Tell-Danun alkali basalt volcano, Harrat as Shamah, Syria, Int. Geol. Rev., 35, $1104-1120$

Sobolev, S. V., A. Petrunin, Z. Garfunkel, A. Y. Babeyko, and D. Group (2005), Thermo-mechanical model of the Dead Sea Transform, Earth Planet. Sci. Lett., 238, 78-95, doi:10.1016/j.epsl.2005.06.058.

Stein, M., and A. W. Hofmann (1992), Fossil plume head beneath the Arabian lithosphere?, Earth Planet. Sci. Lett., 114, 193-209, doi:10.1016/0012-821X(92)90161-N

Stewart, K., and N. Rogers (1996), Mantle plume and lithosphere contributions to basalts from southern Ethiopia, Earth Planet. Sci. Lett., 139, 195-211, doi:10.1016/0012821X(96)00015-5.

Stoeser, D. B., and C. D. Frost (2006), Nd, Pb, Sr, and O isotopic characterization of Saudi Arabian Shield terranes, Chem. Geol., 226, 163-188, doi:10.1016/j.chemgeo.2005.09.019.

Sun, S. S., and W. F. McDonough (1989), Chemical and isotopic systematics of oceanic basalts; implications for mantle 
composition and processes, in Magmatism in the Ocean Basins, edited by A. D. Saunders and M. J. Norry, pp. 313-345, Geol. Soc. of London, London.

Tarawneh, K., S. Ilani, I. Rabba, Y. Harlavan, S. Peltz, K. Ibrahim, R. Weinberger, and G. Steinitz (2000), Dating of the Harrat Ash Shaam basalts, northeast Jordan (Phase 1), Geol. Surv. Isr. Rep. GSI, 2/2000, 59 pp., Nat. Resour. Auth., Amman, Jordan.

Ukstins, I. A., P. R. Renne, E. Wolfenden, J. Baker, D. Ayalew, and M. Menzies (2002), Matching conjugate volcanic rifted margins: ${ }^{40} \mathrm{Ar} /{ }^{39} \mathrm{Ar}$ chrono-stratigraphy of pre- and syn-rift bimodal flood volcanism in Ethiopia and Yemen, Earth Planet. Sci. Lett., 198, 289-306, doi:10.1016/S0012$821 \mathrm{X}(02) 00525-3$

Vidal, P., C. Deniel, P. J. Vellutini, P. Piguet, C. Coulon, J. Vincent, and J. Audin (1991), Changes of mantle sources in the course of a rift evolution: The Afar case, Geophys. Res. Lett., 18, 1913-1916, doi:10.1029/91GL02006.

Weinstein, Y., O. Navon, R. Altherr, and M. Stein (2006), The role of lithospheric mantle heterogeneity in the generation of Plio-Pleistocene alkali basaltic suites from NW Harrat Ash Shaam (Israel), J. Petrol., 47, 1017-1050, doi:10.1093/ petrology/eg1003.

White, R., and D. McKenzie (1989), Magmatism at rift zones: The generation of volcanic continental margins and flood basalts, J. Geophys. Res., 94(B6), 7685-7729.

Wright, J. D., and K. G. Miller (1996), Control of North Atlantic deep water circulation by the Greenland-Scotland Ridge, Paleoceanography, 11, 157-170, doi:10.1029/ 95PA03696. 